\title{
Identification keys for Terebellomorpha (Polychaeta) of the eastern Atlantic and the North Polar Basin
}

\author{
I.A. Jirkov¹, M.K. Leontovich² \\ Department of Hydrobiology, Moscow Lomonosov State University, 119899, Moscow, Russia. \\ e-mail: ${ }^{1}$ ampharete@yandex.ru; ${ }^{2 a x i o n i c e @ m a i l . r u ~}$
}

ABSTRACT. New user-friendly identification keys for 117 species of Pectinariidae, Ampharetidae, and Terebellidae from the eastern Atlantic and the North Polar Basin are presented. A new species Auchenoplax worsfoldi sp.n. is described. Three names Amphitrite affinis, Pista malmgreni, and Terebellides irinae are proposed as junior synonyms to other species.

How to cite this article: Jirkov I.A., Leontovich M.K. 2013. Identification keys for Terebellomorpha (Polychaeta) of the eastern Atlantic and the North Polar Basin // Invert. Zool. Vol.10. No.2. P.217-243.

KEY WORDS: identification key, Polychaeta, Pectinariidae, Ampharetidae, Terebellidae, Eastern Atlantic, North Polar Basin.

\section{Ключи для определения Terebellomorpha (Polychaeta) Восточной Атлантики и Северного Ледовитого океана}

\author{
И.А. Жирков ${ }^{1}$, М.К. Леонтович ${ }^{2}$
}

Кафедра гидробиологии, Биологический факультет, Московский государственныий университет им. М.В. Ломоносова, 119899, Москва, Россия.

e-mail: 'ampharete@yandex.ru; ${ }^{2}$ axionice@mail.ru

РЕЗЮМЕ. Составлены новые ключи для определения 117 видов Pectinariidae, Ampharetidae и Terebellidae Восточной Атлантики и Северного Ледовитого океана. При составлении ключей особое внимание было обращено на лёгкость их использования. Описан новый вид Auchenoplax worsfoldi. Три названия: Amphitrite affinis, Pista malmgreni, и Terebellides irinae - предложено рассматривать как младшие синонимы других названий.

Как цитировать эту статью: Jirkov I.A., Leontovich M.K. 2013. Identification keys for Terebellomorpha (Polychaeta) of the eastern Atlantic and the North Polar Basin // Invert. Zool. Vol.10. No.2. P.217-243.

КЛЮЧЕВЫЕ СЛОВА: определительный ключ, Polychaeta, Pectinariidae, Ampharetidae, Terebellidae, Восточная Атлантика, Северный Ледовитый океан.

\section{Introduction}

The keys cover the shelf of the eastern Atlantic (to the north, from the Bay of Biscay) and the North Polar Basin (shelf and deep water). Some Mediterranean species are also included as they may later be found in the main area covered. Additional general faunistic works treating Terebellomorpha in the North East Atlantic and the Arctic include Fauvel (1927), Hartmann-Schröder (1971, 1996), Holthe (1976), (Jirkov, 2001). The species list is given in the Appendix. 


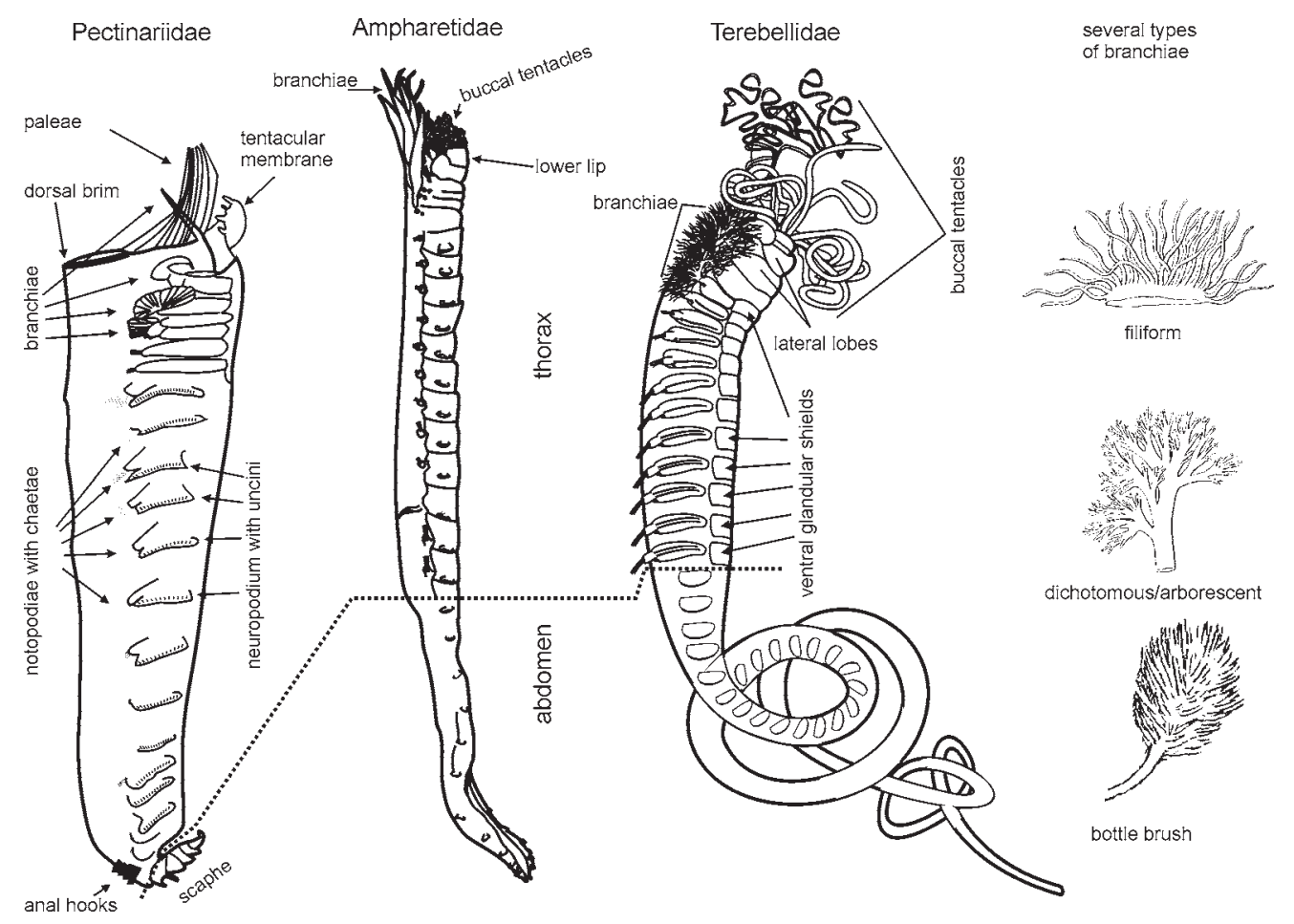

Fig. 1. External morphology of Terebellomorpha. Рис. 1. Наружная морфология Terebellomorpha.

The terebellomorph Polychaeta are bristle worms of small to medium, seldom large, size. The largest species in European waters may reach a length of about $20 \mathrm{~cm}$, but most species are $2-10 \mathrm{~cm}$ in length. Three families are known from the area: Pectinariidae, Ampharetidae and Terebellidae. Some authors include Sabellariidae in Terebellomorpha but we do not accept this.

Terebellomorph polychaetes can be found from the intertidal to depths of more than $9 \mathrm{~km}$, in all types of substrata, but especially in soft sediments and among stones and kelp. All of them are deposit feeders, usually surface, sometimes subsurface, and some (Lanice conchilega at least) can feed by filtering water. Almost all Terebellomorpha build tubes, which are very characteristic for pectinariids (as a family); tube structure is sometimes a species-specific character.

\section{External morphology (Fig 1)}

Terebellomorpha is an order of Polychaeta which is characterised by the presence of buccal tentacles, notopodia with simple bristles and neuropodia with uncini. Terminology for the segmentation of the anterior end differs slightly between publications and can be a source of confusion. However, for the keys presented here, the problems are avoided.

The body of Terebellomorpha can be subdivided into the thorax and abdomen. The thorax is the anterior part of the body with notopodia. The abdomen is the posterior part of the body, without notopodial chaetae (rudimentary notopodia without chaetae may be present). Neuropodia are usually present in the abdomen, but Pectinariidae and some Polycirrinae have no abdominal neuropodia. Some Terebellinae have notopodia on all or almost all segments, in these cases there is no distinct thorax/abdomen subdivision. 


\section{Taxonomy}

The taxonomic system accepted here follows Jirkov (2001, 2011) and Jirkov et al. (2001), except for the generic diagnoses within the Trichobranchinae, which follows Muir (2010). Several authors accept Trichobranchinae as a family but, in our opinion, this is not correct, and now an increasing number of polychaetologists share the same opinion. Generic definitions and numbers of genera are matters for discussion.

\section{Identification}

All characters mentioned in the first sentence of each key couplet are obligate. Characters mentioned in the second sentence are not obligate but can often help in identification. To shorten and simplify the keys, some steps have more than two alternatives, so take care. It is strongly recommended to identify several specimens together rather than a single individual. Use of methyl blue often makes morphological characters more visible.

The most important characters for different families differ considerably but, usually for identification, it is necessary to count segments with different types of parapodia. For most characters mentioned in the key it is not necessary to prepare slides and use a compound microscope. Even double rows of uncini can usually be seen under a stereomicroscope with some experience, though it is initially better to check under a compound microscope. In only a few cases is use of a compound microscope necessary within the Terebellidae key, where we did not have enough material for investigation of external morphology to find better characters. In most cases, low (100-200 times) magnification will be enough. In small specimens, chaetae can be viewed directly from specimens placed upside-down under a coverglass. In larger specimens it is necessary to tear off a neuropodium for examination. Some additional remarks for identification are given in appropriate places in the keys.

Figures shown to the left or uppermost relate to the first part of the couplet, those shown to the right or lowermost relate to the second. If only one figure is present, it relates to the first part of the couplet.

Geographical range is a species characteristic, and is given for each species.

\section{Explanation of terms, used in keys}

Avicular uncini - flattened uncini with a short or long shaft and a large rostrum (also called a beak or fang) with one or more rows of secondary teeth distally.

Branchiae - notopodial cirri of anterior segments, they may be of several different shapes.

Branchophore and branchostyle - as the branchiae of Terebellomorpha are obviously forms of dorsal cirri, these terms are used for the basal and distal joints of branchiae analogous to the cirrophore and cirrostyle.

Buccal tentacles - tentacles attached within or near the mouth.

Nephridial papilla - a papilla including the external opening of one of the excretory organs.

Paleae (single - palea) - simple, often enlarged, forward-pointing notochaetae of the first chaetiger in Pectinariidae and some Ampharetidae.

Pectinate uncini - small flattened chaetae (in terebellomorphs always neurochaetae) with a short shaft and one or more vertical rows of large teeth giving a comb-like appearance.

Ventral glandular shield - the delimited ventral surface of a thoracic segment, usually covering glandular tissue, thicker and usually more whitish than neighbouring parts.

Uncini (single - uncinus) - plates with teeth. The structure of uncini (number and arrangement of teeth) is one of the most important taxonomic characters.

For species ranges, we used terms explained in our paper (Jirkov, Leontovich, 2012).

\section{Abbreviations}

$\mathrm{AU}$ - abdominal unciniger.

$\mathrm{S}$ - segment.

$\mathrm{C}$ - chaetiger.

$\mathrm{TC}$ - thoracic chaetiger.

$\mathrm{TU}$ - thoracic unciniger. 
An abbreviation with a number refers to a segment: i.e. S2 means the second segment Numbers in brackets indicate ranges of values.
No one key is complete and perfect. If you have any difficulties or problems, do not hesitate to contact us by e-mail or by other means.

\section{Pectinariidae}

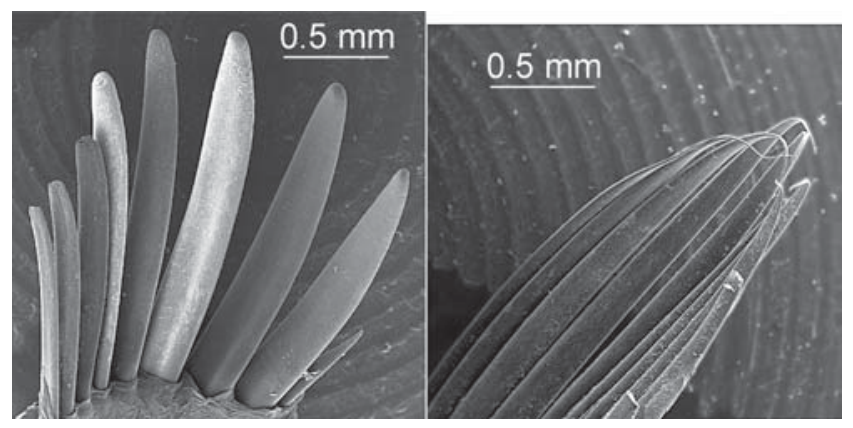

1. Tips of paleal chaetae blunt . 2

— Tips of paleal chaetae tapering Pectinaria (partim)...3

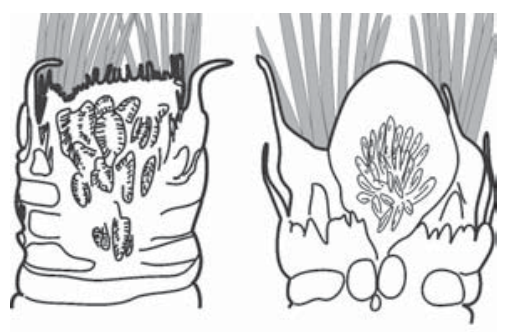

2. Tentacular membrane serrated . Pectinaria granulata Shallow water, high Boreal.

— Tentacular membrane smooth Petta pusilla

Shallow water, Boreal-Lusitanian.

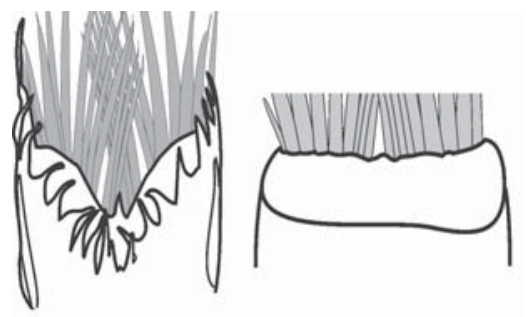

3. Dorsal brim with cirri

Pectinaria auricoma

— Dorsal brim smooth

Sublittoral-bathyal, widespread Boreal.

4. $12 \mathrm{TU}$

5

$-13 \mathrm{TU}$

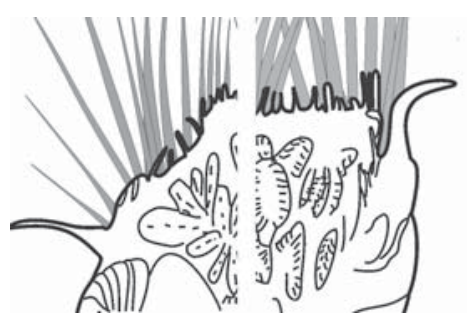

Pectinaria belgica

Shallow water, Boreal-Lusitanian

5. Tentacular membrane joined with the base of first pair of branchiae Pectinaria koreni Shallow water, widelspread Boreal. - Tentacular membrane free; does not with base of first pair of branchiae 


\section{Ampharetidae}

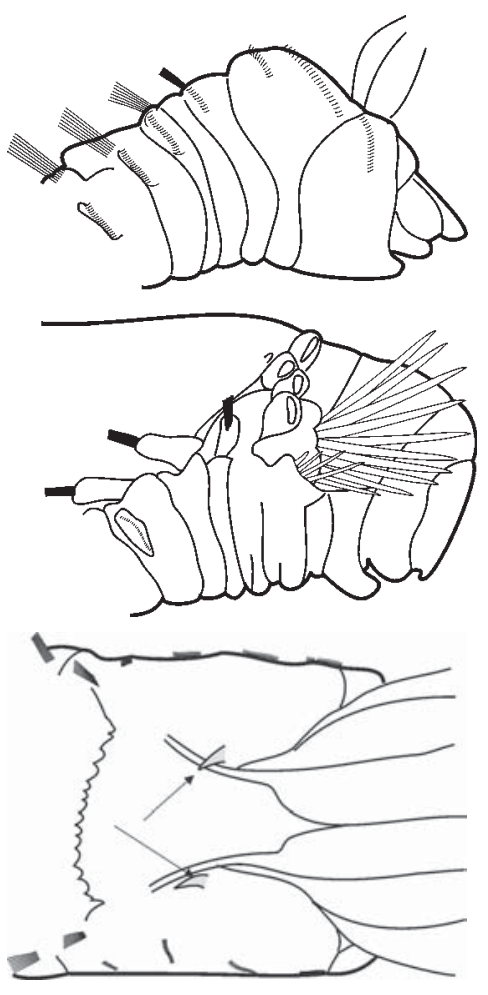

1. 3 or 4 anterior segments with row of minute acicular chaetae, all following segments with normal uncini. Usually with hooks behind branchiae; paleae absent

Melinninae...2

- Anterior segments without rows of minute acicular chaetae. Hooks behind branchiae always absent, paleae often present Ampharetinae...6

2. Hooks (grey, pointed) and membranous fold present behind branchiae

Melinna..3

- Hooks and fold behind branchiae absent

Melinnopsis arctica

High Arctic deep water, absent from the Norwegian Sea.

3. 3 anterior segments with minute acicular chaetae Melinna palmata

Low Boreal, Lusitanian.

- 4 anterior segments with minute acicular chaetae 4

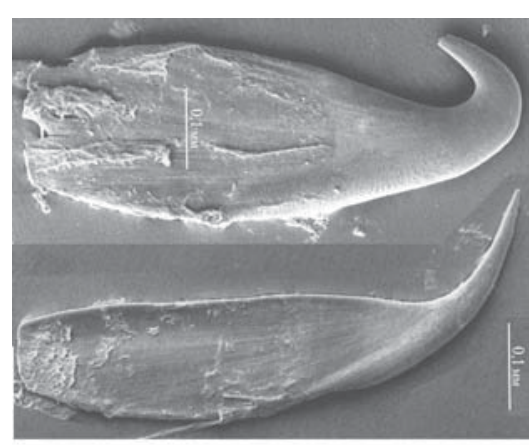

4. Tips of dorsal hooks strongly curved 5

— Tips of dorsal hooks weakly curved

Melinna cristata

Shelf, Arcto-Boreal.

— Dorsal hooks almost straight

Melinna collare

Atlantic deep water 


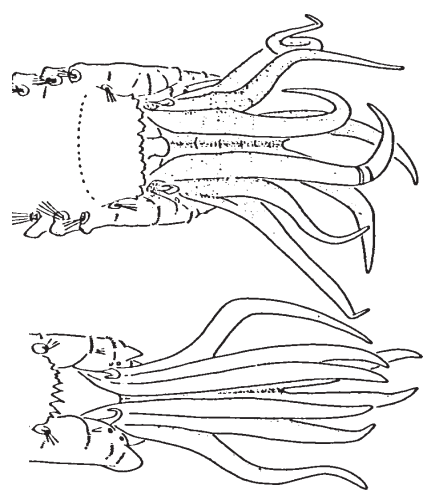

5. Inner branchiae with white bands Melinna albicincta Low Boreal-Lusitanian. shelf.

— Inner branchiae without white bands .. Melinna elisabethae Shelf, arcto-Boreal.

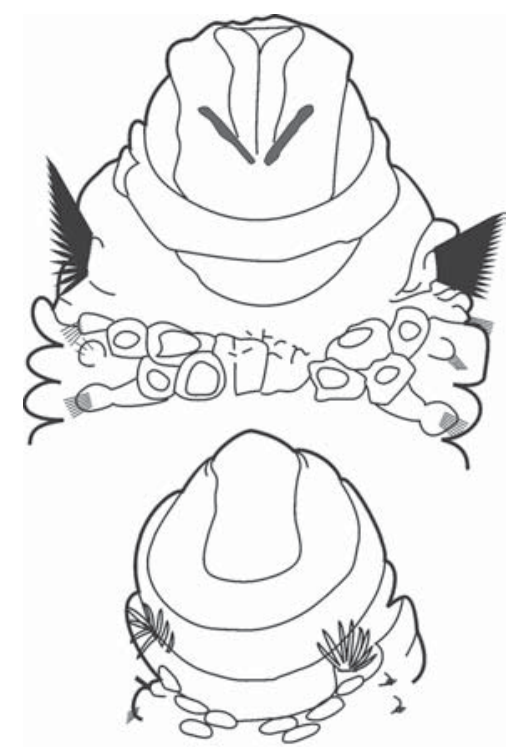

6. Prostomium with two longitudinal ridges protruding anteriorly as horns and two transversal nuchal organs. Paleae well developed, paleal chaetae longer than the most developed notochaetae. $14 \mathrm{TU}$ Amphicteis...7

— Prostomium without transversal nuchal organs and usually without prominent longitudinal ridges (if present paleae minute or absent), with U-shaped groove. 11

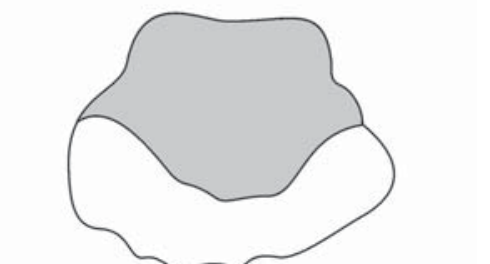

- Prostomium simple lobe without transversal nuchal organs, longitudinal ridges or U-shaped groove 35

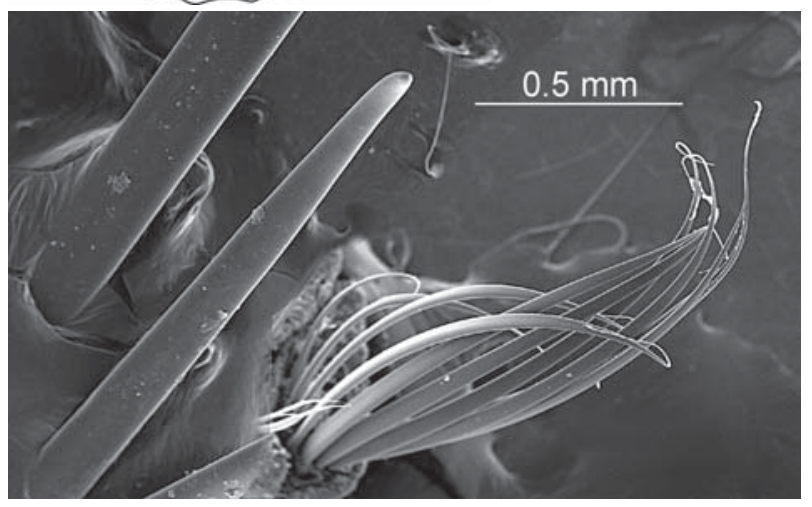

7. Tips of paleal chaetae blunt .....8

- Tips of paleal chaetae evenly tapering 9 
8. Paleal chaetae dark brown; usually more than 10 paleal chaetae (8-16). Branchiae without bands

Amphicteis ninonae

Bathyal Arctic.

- Paleal chaetae light yellow. Usually (90\%) no more than 8 paleal chaetae (up to 10 . Branchiae usually with dark bands .....

Amphicteis midas

Shallow low Boreal-Lusitanian.

9. $15 \mathrm{AU}$

- 18-20 AU

Amphicteis sundevalli

Upper shelf, high Arctic.

10. Longitudinal ridges of prostomium well marked, abdominal neuropodia with short dorsal cirri

Amphicteis gunneri

Widely distributed shelf species.

— Longitudinal ridges of prostomium inconspicuous, abdominal neuropodia with long dorsal cirri

Amphicteis wesenbergae

Deep water, south to Iceland, Norwegian and Greenland Seas.
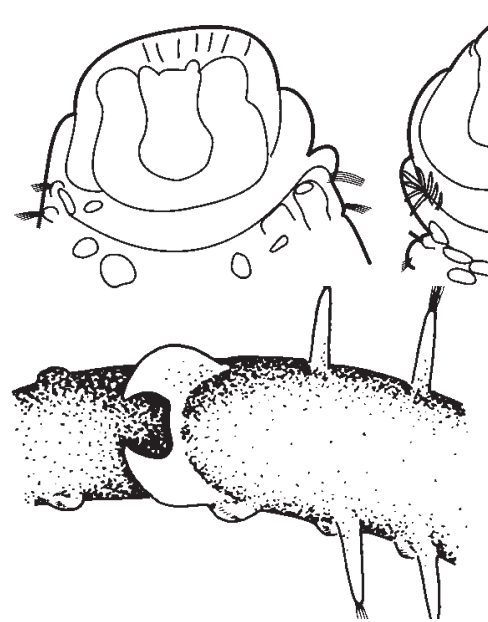

11. Middle lobe of prostomium anteriorly incised (if buccal tentacles are protrunding, incision may be smoothed and the prostomium anteriorly appears broadly rounded) 12 - Middle lobe of prostomium anteriorly rounded or pointed 17

12. AU1 with foliaceous rudimentary notopodia

Ymerana pteropoda Deep water Arctic. - All abdominal rudimentary notopodia small, never foliaceous

13. $11 \mathrm{TU}$ 14

- $13 \mathrm{TU}$; paleae absent

Hypania romijni

Boreal brackish water.

- $13 \mathrm{TU}$; paleae well developed, paleal chaetae longer the most developed notochaetae

Hypania invalida

Boreal fresh and brackish water. Amage adspersa

Low Boreal - Lusitaninan.

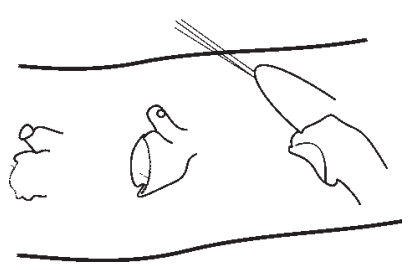

14. At least 19 AU, neuropodia of AU-1 of thoracic type, paleal chaetae shorter than the most developed notochaetae

Grubianella klugei

Deep water Arctic.

- 8 or 9 AU, all abdominal neuropodia of abdominal type, no paleae at all

15. $8 \mathrm{AU}$

Amage auricula

$-9 \mathrm{AU}$

16. 3 pairs of branchiae 


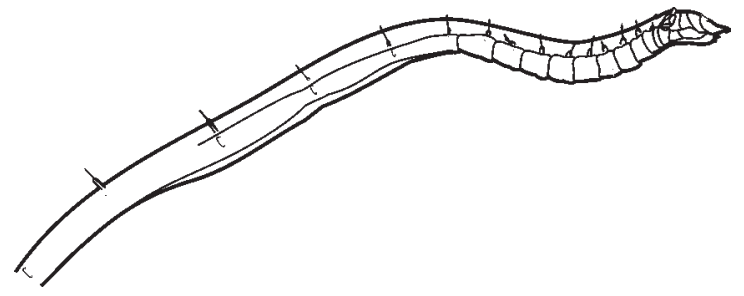

17. Thorax sharply subdivided in two regions: (1) anterior 9-10 TS short with well developed ventral glandular pads, (2) last 5 TU very long, glandular pads not developed 18 — All thoracic segments remain similar in length; glandular pads may reduce gradually or stop abruptly, but the above characters are not combined 19

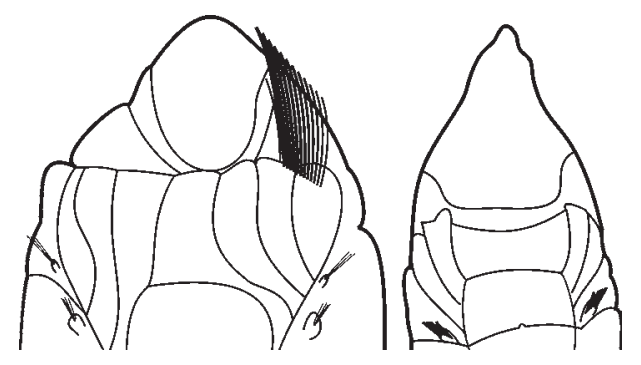

18. Prostomium rounded; paleae present (not shown on left); 3 pairs of branchiae.....

Eclysippe vanelli

Shelf, low (?) Boreal - lusitaninan. - Prostomium pointed, often with terminal papilla; paleae absent; 2 pairs of branchiae .....

Auchenoplax worsfoldi

Lusitanian. See description below

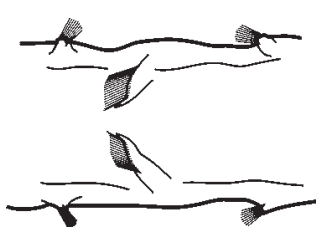

19. Notopodia of TU9 or TU10 foliaceous, others normal

Sosane...20

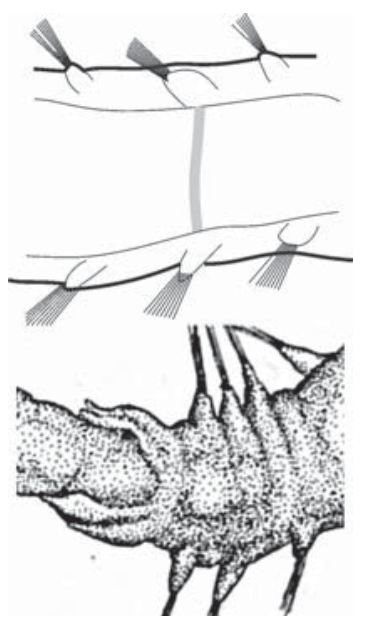

- Notopodia of TU8 (5th from the end of thorax) slightly displaced dorsally and connected by a low glandular band (sometimes visible only after staining), others normal

Anobothrus...23

20. Notopodia of TU9 (last) foliaceous 

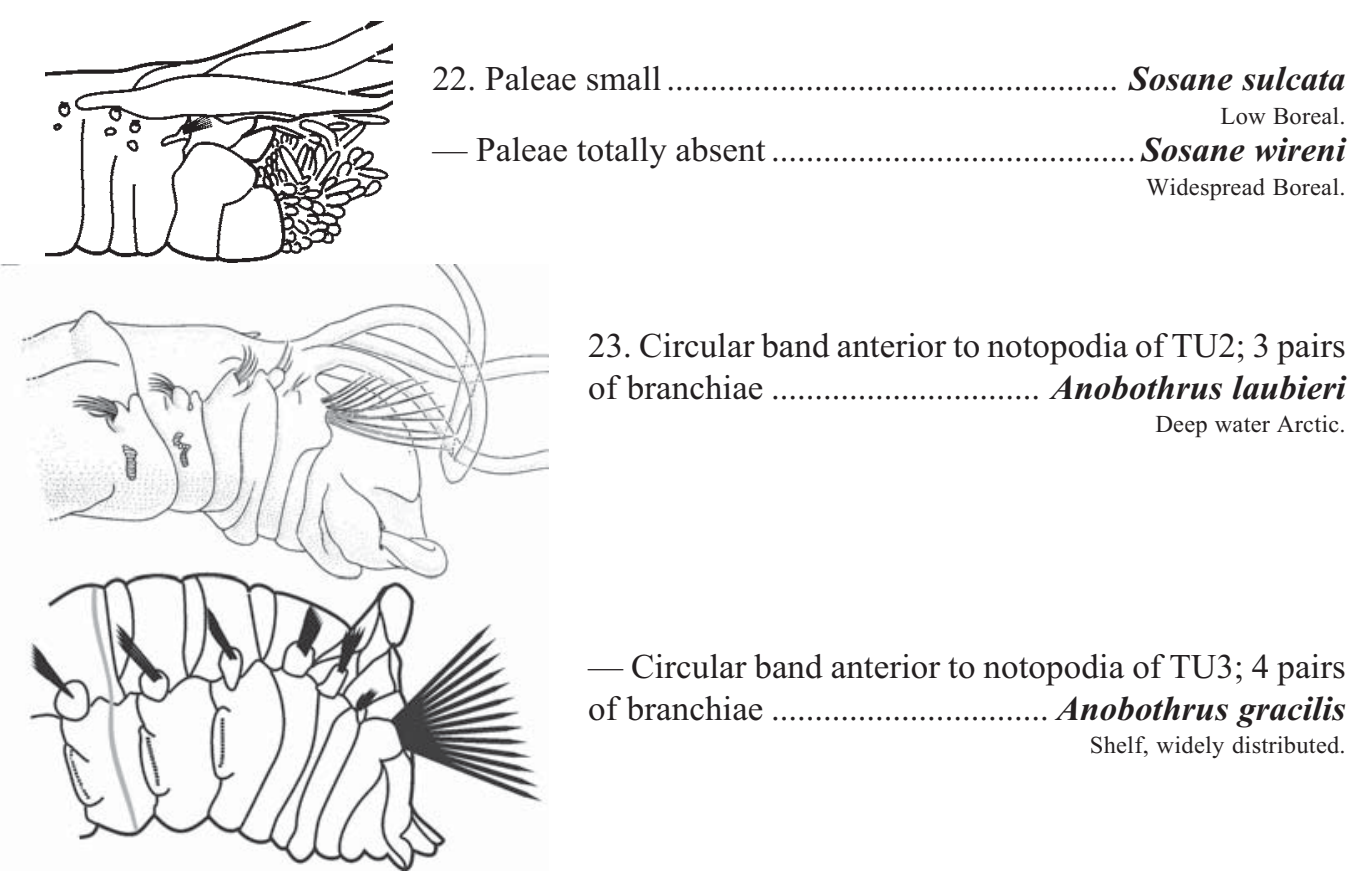

23. Circular band anterior to notopodia of TU2; 3 pairs of branchiae Anobothrus laubieri Deep water Arctic.

— Circular band anterior to notopodia of TU3; 4 pairs of branchiae

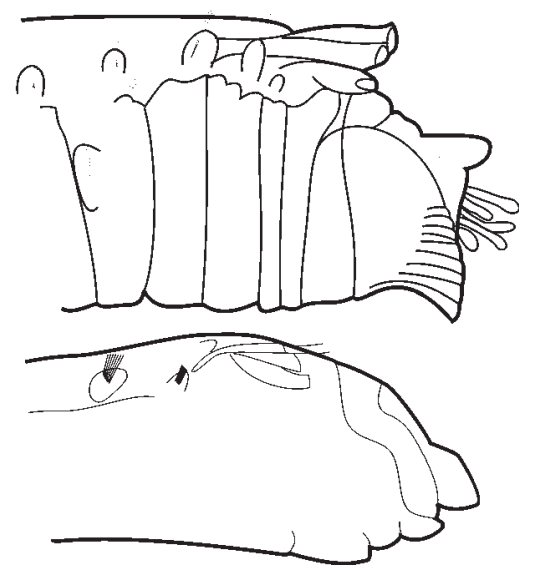

24. Lower lip enlarged, longitudinally folded

Lysippe...25

25. $16 \mathrm{TC}, 13 \mathrm{TU}, 14-15 \mathrm{AU}, 4$ pairs of branchiae

- 17 TC, 14 TU, 13 AU, 3 pairs of branchiae

Shelf, Arctic-high Boreal.

- 17 TC, 14 TU, 8 AU, 4 pairs of branchiae Lysippe sexcirrata

- 17 TC, 14 TU, 8 AU, 4 pairs of branchiae

Shelf, widespread Boreal. Lysippe fragilis 

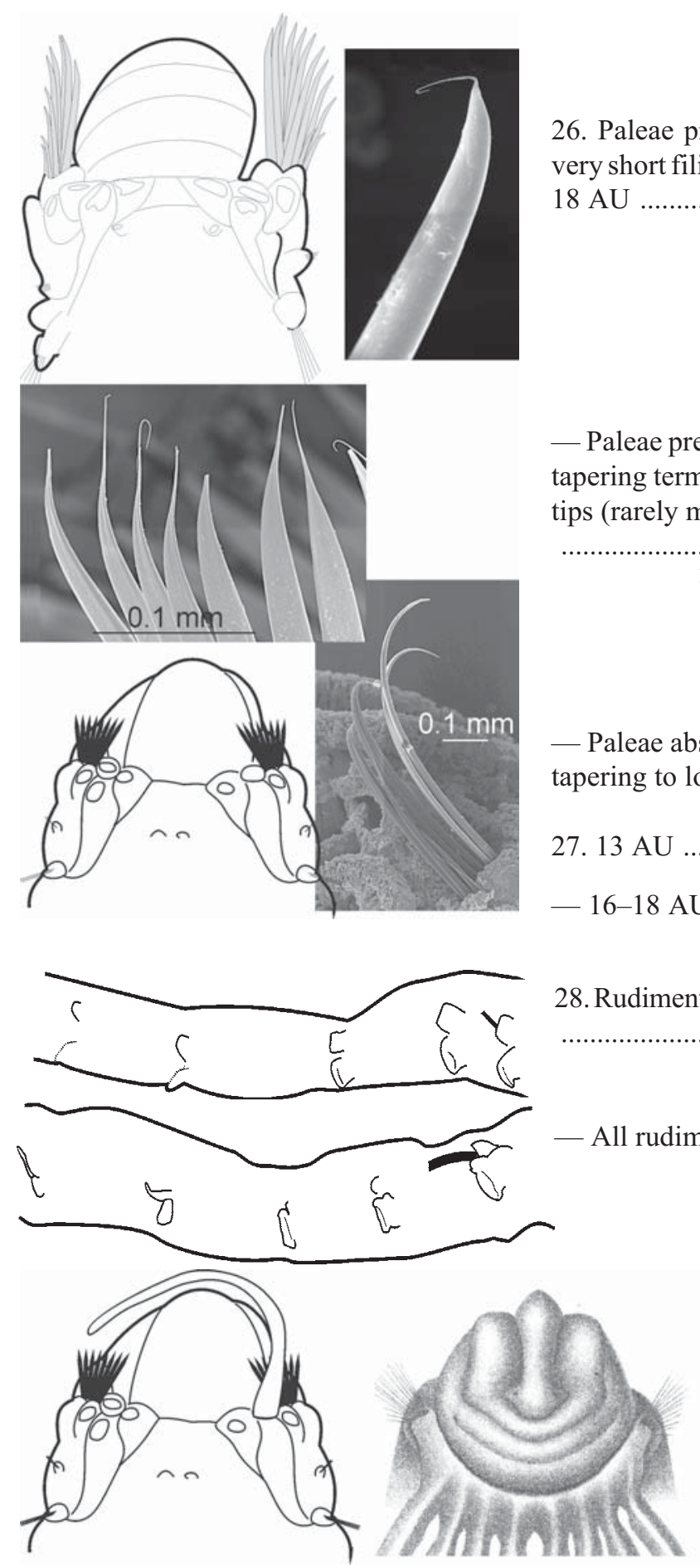

26. Paleae present, stout and abruptly tapered to very short filiform tips (usually missing). 13 or 16$18 \mathrm{AU}$............ agg. Ampharete finmarchica...27

— Paleae present, stout and gradually but strongly tapering terminally to comparatively long filiform tips (rarely missing). $12 \mathrm{AU}$

Ampharete villenai

Deep-water North Atlantic species, 1,605-2,270 m.

- Paleae absent or, if present, slender and evenly tapering to long filiform tip. 12 or 26-28 AU . 28

27. $13 \mathrm{AU}$

Ampharete finmarchica

Shelf, boreo-Arctic.

-16-18 AU

Ampharete goeesi

Shelf, high Boreal and Arctic.

28. Rudimentary notopodia of first two AU enlarged 29

- All rudimentary notopodia of similar size .. 30

30. Palea clearly visible, paleal chaetae large, their length almost equal to body width

- Palea poorly visible, paleal chaetae small, their length several times less than body width 32 


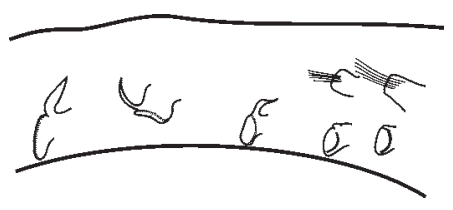

31. Neuropodia of last 14 (usually) chaetigers (all abdominal and two last thoracic) with long cirri .. Ampharete acutifrons

Shelf, widely distributed. Ampharete grubei Malmgren, 1866, according to the original description cannot be synonym of Ampharete acutifrons, because it lacks long neuropodial cirri. — Neuropodial cirri (if present) reduced

agg. Ampharete lindstroemi

Widely distributed group of species with unclear taxonomic relations, besides A. lindstroemi it includes A. grubei, A. baltica and 23 undescribed species
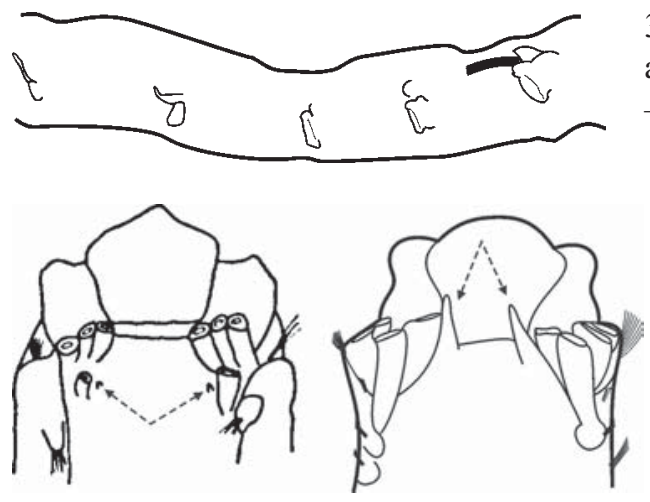

33. Abdominal neuropodia (other than two most anterior) with very long neuropodial cirri ........ 34 - Neuropodial cirri short or absent

Amythasides macroglossus Shelf, low (?) Boreal.

34. Branchiae and nephridial papillae (pointed) as shown; $12 \mathrm{AU}$ Ampharete borealis Shelf, Arctic. - Branchiae and nephridial papillae (pointed) as shown; 15-17 AU Ampharete octocirrata Shelf, Boreal-Lusitanian.

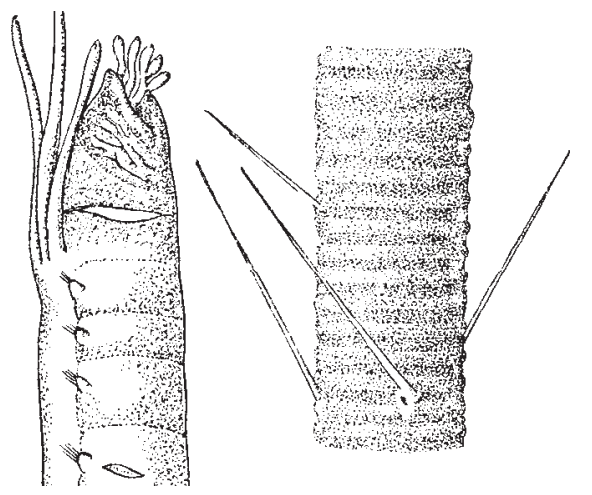

35. Tube muddy with transversal ridges; prostomium with lateral glandular shields

Glyphanostomum pallescens

Mainly slope, widely distributed

- Tube otherwise, prostomium without lateral glandular shields 36

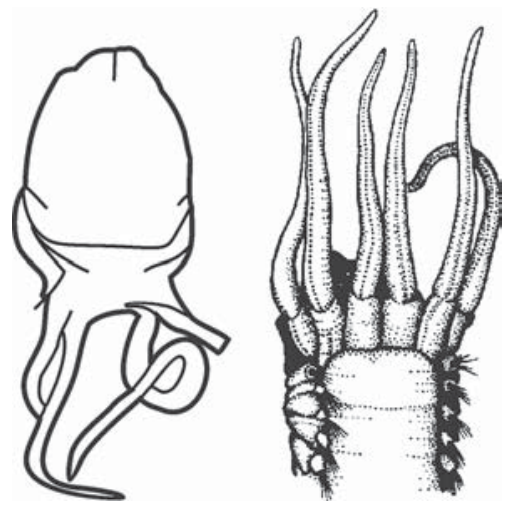

36. 2 pairs of branchiae; 10 TU, TU9 with Anobothrus-type modified notopodia Zatsepinia rittichae Distribution unclear, probably deep water. -3 pairs of branchiae; 12 TU, modified notopodia absent 


\section{Auchenoplax Ehlers, 1887}

The genus was erected by Ehlers (1887) for Auchenoplax crinita. It is characterized by two pairs of branchiae and modified (enlarged and moved ventrally) neuropodia of TU1 and TU2. Hutchings (1977) described Auchenoplax mesos. According to the original description this species has "Eight gill scars arranged in 2 groups of 2 pairs", i.e. in total 4 pairs of branchiae. However, according to Holthe (2002), in her personal communication to him, she corrected the diagnosis of her species; in reality it has only 2 pairs of branchiae.

Ampharetidae live in tubes and they have specialised glands that secrete the matrix for the tubes. As in all other Terebellomorpha these glands are situated on the ventral surface. The most developed glands are situated in the anterior thorax, but they do not form special ventral glandular shields as in some Terebellidae (Noanelia Desbruyeres et Laubier, 1977 is the only exception, but its taxonomic position is not clear to us; it probably belongs to the Terebellidae or to a new undescribed family). Towards the posterior the glandular fields are less developed. Use of methyl blue often makes glandular fields more visible. All thoracic segments are similar in length. However the thorax of Auchenoplax crinita and the new species is in conrast to almost all other ampharetids, sharply subdivided into two regions: (1) anterior 9-10 TS short with well developed ventral glandular pads, (2) last 5 TU very long, glandular pads not developed. This subdivision is very sharp, there are no transitional segments. The segments of the second part of thorax are additionally modified: all of them have low transverse ridges, connecting the notopodia. The development of these ridges varies: the ridges of some specimens are complete while those of others are developed only near notopodia and are absent in the mid dorsum. Again use of methyl blue makes the structures more visible, which explains why these ridges were overlooked by previous investigators. The notopodia of the second part of the thorax are slightly flattened. Among other ampharetids, only Eclysippe spp. have the same subdivision of the thorax, which in our opinion reflects the similarity of these genera; however, Eclysippe has no modified neuropodia, and has 3 pairs of branchiae and well developed paleae; these differences are enough to accept the two genera as distinct.

Thus, the generic diagnosis should be changed. The new diagnosis is as follows:

Diagnosis. Prostomium Ampharete-type. Thorax distinctly subdivided into two regions: anterior segments (up to TC9) several times shorter those of posterior region. Neuropodia of TU2 and/or TU1 enlarged and displaced ventrally. Notopodia of posterior TU slightly displaced and connected by more or less developed transverse dorsal ridges.

The genus in this sense currently includes 4 species.

1. A. andamana Holthe, 2002;

2. A. crinita Ehlers, 1887;

3. A. mesos Hutchings 1977;

4. A. worsfoldi sp.n.

Holthe (1986) proposed the new name Auchenoplax rullieri Holthe, 1986 for Ampharetidae gen. et sp. indet. Rullier (1972). However, the original and only description (Holthe provided no additional information) is in our opinion too brief to be sure that this species is really an Auchenolpax.

Also, Melinnoides nelsoni Behnam, 1927 probably belongs to Auchenoplax as, according to the original description, the species has enlaged neuropodia at least in anterior TU. Unfortunately, when one of us (IJ) tried to examine the type, he have found only a tube and no worm. This species should, therefore, be accepted as insertae sedis due the loss of the type and the inadequancy of the original description.

Some other species of Auchenoplax have been found in examined material from the Bering Sea and Vietnam; however there is not enough material for new species to be described. As a new species is described and the generic diagnosis is changed, a re-description of the holotype of the type species is provided along with the description of the new species. 


\section{Auchenoplax crinita Ehlers, 1887}

Fig. 2e,f.

Auchenoplax crinita Ehlers, 1887: 209-214, pl. 44, fig. 10-16 (type: ZMH V-3247, type locality: $24^{\circ} 03^{\prime} \mathrm{N}$, 82 $51^{\prime} \mathrm{W}$; Hartman, 1965: 216-217, pl. 47

Material studied: holotype.

Prostomium Ampharete-type, middle lobe slim, terminally rounded, slightly expanded at the base. Holotype without buccal tentacles; according Hartman (1965), they are small, smooth and numerous. According to the original description, paleae present ("Paleenbundel vorhanden, doch sehr klein"); however, we could not find them in the type material; there are small rudimentary warts instead. Augener probably misidentified the first pair of notopodia as paleae. Two pairs of branchiae, separated middorsally by a gap equal to the width of one branchial group. Inner branchophores connected by a high dermal fold. This fold and branchophores form high transverse ridge. There is no clear connection between branchophores and notopodia. Branchiae attached to S3, as correctly stated by Hartman (1965). 14 TC, 12 TU. Neuropodia of TU1 and TU2 enlarged; the rows of their uncini are approximately 5 times longer than the rows of uncini in the other TC. Neuropodia of TU1 prolonged ventrally, but their upper margins are at the same level as those of the neuropodia of TU3. Neuropodia of TU2 displaced ventrally, their upper margins situated only slightly above the lower margin of the neuropodia of TU1; ventral margins of neuropodia of TU2 separated by a distance shorter than the length of the row of their uncini. Other neuropodia of TC much smaller. Thorax sharply subdivided into two regions. Segments of anterior region (up to TC-9) several times shorter those of posterior region. There are no transitional segments. Glandular pads occupy whole of ventral surface between the notopodia of the anterior thoracic segments; five posterior TC without glands. Notopodia of anterior thoracic region cylindrical, those of posterior slightly flattened, and slightly displaced dorsally; no visible dorsal ridges. About 14 AU (holotype slightly dried); Hartman (1965) mentioned 1228 AU. Abdominal segments without rudimentary notopodia and cirri. Pigidium with a pair of minute lateral cirri.
Remark. This species have been widely reported (Fauvel, 1936: 95-96; Kirkergaard, 1959: 80; Gallardo, 1968: 126; Al-Hakim, Glasby, 2004: 40); however these reports are usually not accompanied with sufficiently detailed descriptions to be sure of the correct identification.

\section{Auchenoplax worsfoldi sp.n.}

Fig. $2 \mathrm{a}-\mathrm{d}$.

Material: 44 worms from 6 samples from the Aquitaine Basin, Bay of Biscay (ORCA-1, Aquitaine Maritime Prospect): Samples 1B (40908/58308), muddy sand; 2A (40909/ 58304), sand; 3B (40912/58300), muddy sand; 4B (40914/ $58301)$, muddy sand; 7A (40919/58307), sand and 8B (40922/58305), muddy sand. HOLOTYPE from Sample 7A (40919/58307). All samples were collected on 12 April 2007 in the vicinity of $44^{\circ} 75^{\prime} \mathrm{N}, 01^{\circ} 78^{\prime} \mathrm{W}, 109-110 \mathrm{~m}$. All samples were $0.1 \mathrm{~m}^{2}$. Day grabs sieved at $0.5 \mathrm{~mm}$.

HOLOTYPE from sample 40919/58307. $44^{\circ} 75^{\prime} \mathrm{N}$, $01^{\circ} 78^{\prime} \mathrm{W}, 109.4-110.4 \mathrm{~m} .0 .1 \mathrm{~m}^{2}$. Day grabs sieved at 0.5 $\mathrm{mm}$. Material is deposed in the collection of the Department of Hydrobiology.

Middle lobe of prostomium sharply pointed or with short papilla on the tip. There is a pair of transverse furrows (nuchal organs) near the middle of the prostomium; there is also a $\mathrm{U}$ shaped furrow, dividing the prostomium into lobes. Few smooth buccal tentacles. Paleae totally absent. Two pairs of branchiae, separated mid dorsally by a gap equal to the width of one branchial group. Inner branchophores connected by a high dermal fold. This fold and branchophores form a high transverse ridge. This ridge usually abuts onto the dorsum, so that it is hardly visible on fixed specimens, unless a needle is placed below. There is no visible connection between branchophores and notopodia. Branchostyles smooth cirriform and equal. There is a small mid dorsal nephridial papilla between the 1 st pair of notopodia. 14 TC, 12 TU. Thorax sharply subdivided into two regions. Segments of anterior region (up to TC9) several times shorter those of posterior region. There are no transitional segments. Glandular pads occupy whole of ventral surface between notopodia of anterior thoracic segments; five posterior TC without glands. Notopodia of anterior thoracic region cylindrical, those of posterior slightly flattened and slightly displaced dorsally. Neuropodia start from TC3; 


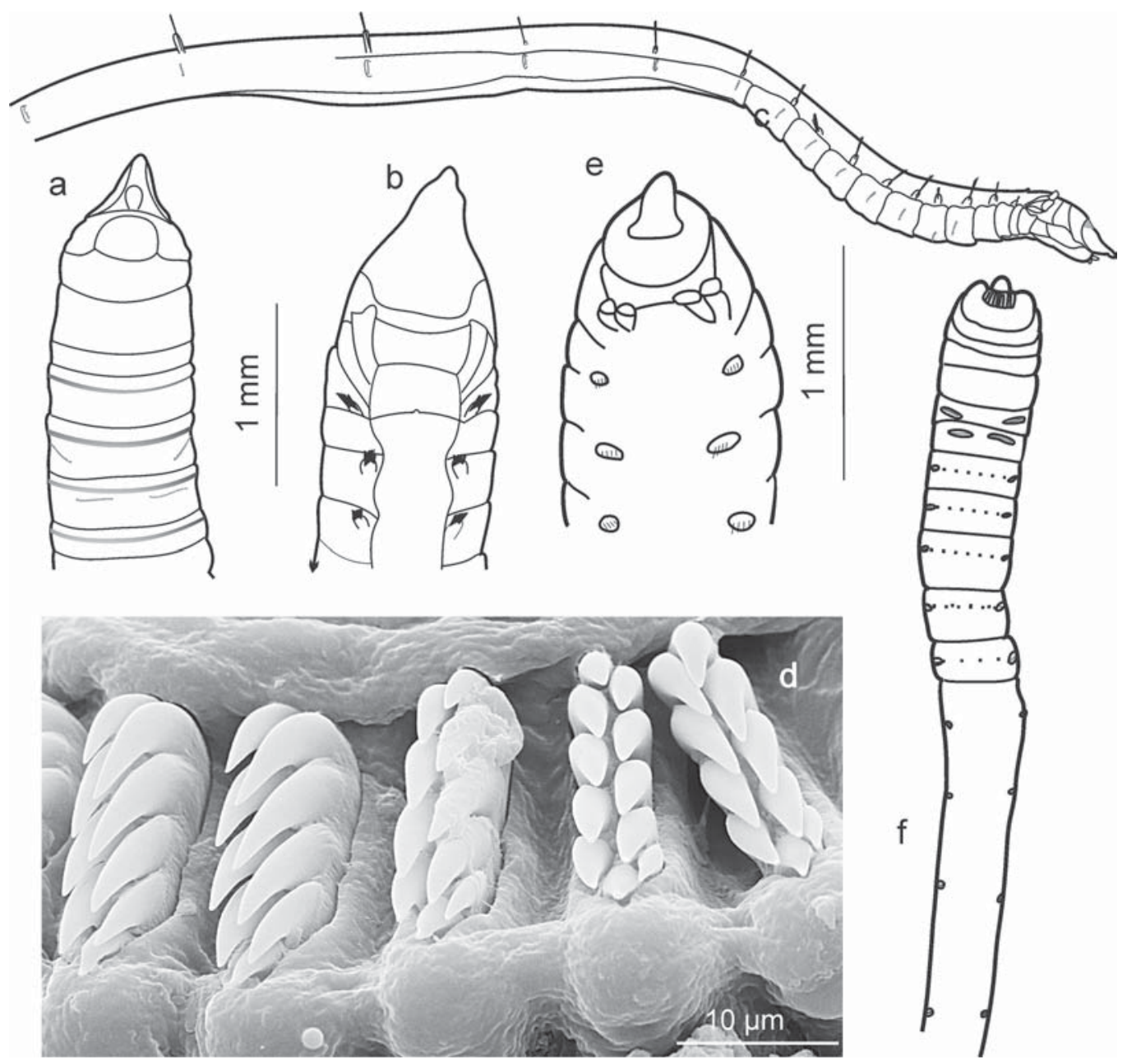

Fig. 2. Auchenoplax spp.: a-d-A. worsfoldi (a-c- holotype), e, $\mathrm{f}-A$. crinita, holotype; a,f - ventral view, b,e - dorsal view, c - lateral view, d - uncini.

Рис. 2. Auchenoplax spp.: a-d-A. worsfoldi (a-c-голотип), e, f-A. crinita, голотип; а, $\mathrm{f}-$ вид снизу, b,e - вид со спины, с - вид сбоку, d — uncini.

dorsal margin of row of uncini on TU1 on the same level as those of TU3, but length of the row of uncini on TU1 twice that of TU3 and row slightly slanted (ventral margin situated distinctly posterior to dorsal). Row of uncini on TU2 distinctly displaced ventrally: dorsal margins only slightly above ventral margin of TU1 row. Length rows of uncini on TU1 and TU2 twice that of TU3 row; distance between ventral margins of TU2 rows 2-3 times less than the length of the row. 12 AU. Neuropodia of first two AU of thoracic type (uncinigerous tori), others of abdominal type (uncigerous pinnules). Neuropodia of six anterior AU joined by low ciliated ridges, identical to the thoracic ridges of Elysippe vanelli. Some TC may also possess such ridges, but they are weakly developed, often present near notopodia only and absent mid dorsally. If present, ridges reduced anteriorly, usually visible on 1-2 last TC but, in large worms, visible on all five. All ridges visible only on well preserved worms. Some well preserved worms, however, have no trace of ridges, despite smaller worms from the same sam- 
ple having them. All worms with oocytes in the body cavity were without ridges, so it is probable that ridges are present in the male only (sexual dimorphism). Neuropodia without cirri; rudimentary notopodia absent. Pygidium with pair of lobes, without cirri. Worms very slim (less than $1 \mathrm{~mm}$ ) and long (up to $30 \mathrm{~mm}$ ). Tube formed single layer of sand grains without mud or detritus. Notochaetae short, hirsute and long, smooth, each forming a row. Neurochaetae with teeth in two rows, each including 4 or 5 teeth, with an unpaired tooth proximally (Fig. 2d). Methyl blue stain: glandular pads raspberry pink with slim transverse blue bands between notopodia; rest of body light blue.
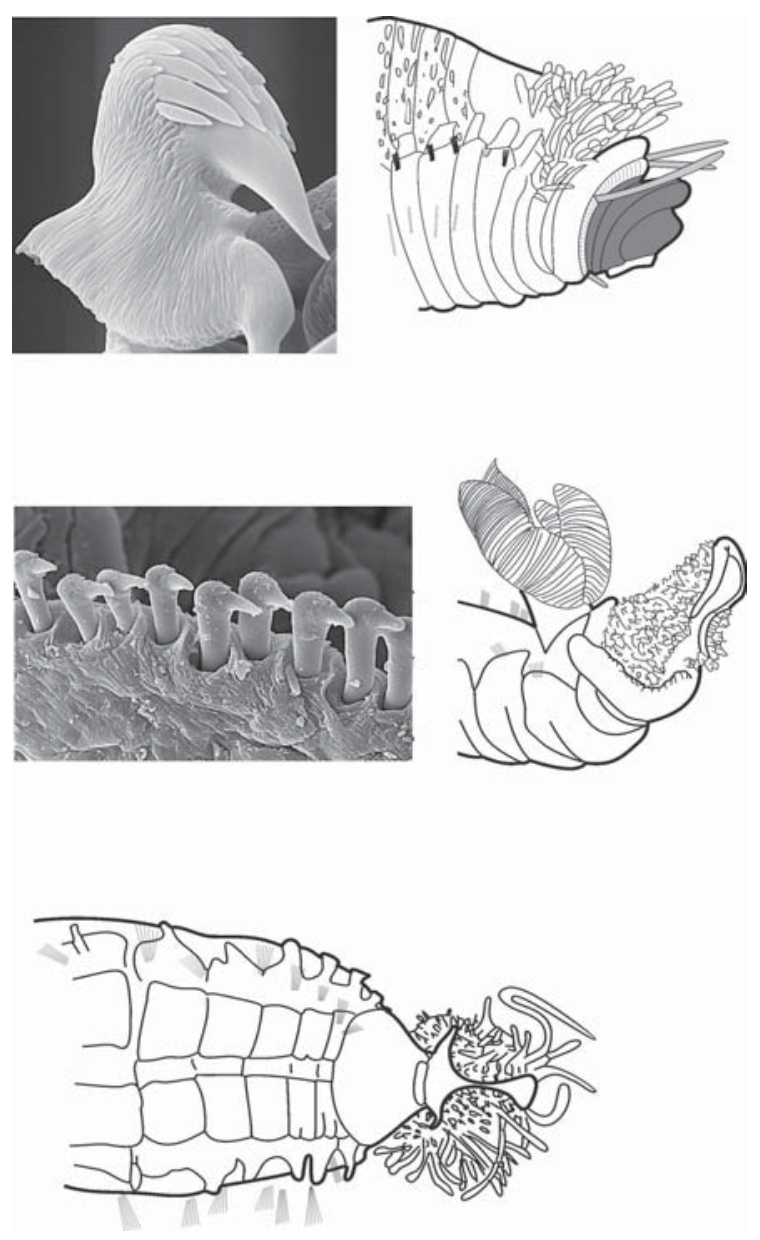
AU.
Etymology. Species named after my friend Tim Worsfold (APEM Limited), who transfered material to me.

Differential diagnosis. Auchenoplax mesos, A. andamana and A. rullieri have modified neuropodiae on TU2 only. A. crinita has more

Distribution. Probably other reports from the East Atlantic: west Africa (Fauvel, 1932; Kirkergaard, 1959; Intes, Le Loeuff, 1977, 1984), Meditteranean (Laubier, 1966; Cocito et al., 1990; Martinalli et al., 1998) and Atlantic Iberian Peninsula (Gil, Sarda. 1999; Martinez, Adarraga, 2001; Parapar, Moreira, 2009) also belong to the new species, while West Atlantic reports belong to $A$. crinita s.str.

\section{Terebellidae}

1. Upper lip (dark grey) usually small, buccal tentacles (light grey) attached behind (above) it; if lost, attachment scars are visible. Branchiae, if present, of various shapes, often branched (if absent uncini always in double rows); ventral glandular shields, if present, usually one pair per segment; uncini avicular or pectinate, often in double rows in posterior thorax

Terebellinae...2

- Upper lip large, buccal tentacles attached to (on) it. Branchiae always present, various shapes, but never branched; ventral glandular shields absent; thoracic uncini with long shafts, abdominal uncini without; never in double rows

Trichobranchinae...30

- Upper lip large, buccal tentacles attached to (on) it (may cover whole surface or limited to margins or to bases) or more rarely behind it. Branchiae always absent; ventral glandular shields three per segment, split by two longitudinal furrows; medial shield often much smaller (sometimes reduced) than lateral shields; sometimes lateral shields poorly developed with only a small medial one visible; thoracic uncini never in double rows, often totally absent

Polycirrinae...34

Reduced parapodia are characteristic for the subfamily. Noto- and neuropodia often hardly visible. We recommend using methyl blue even if everything seems clear. 

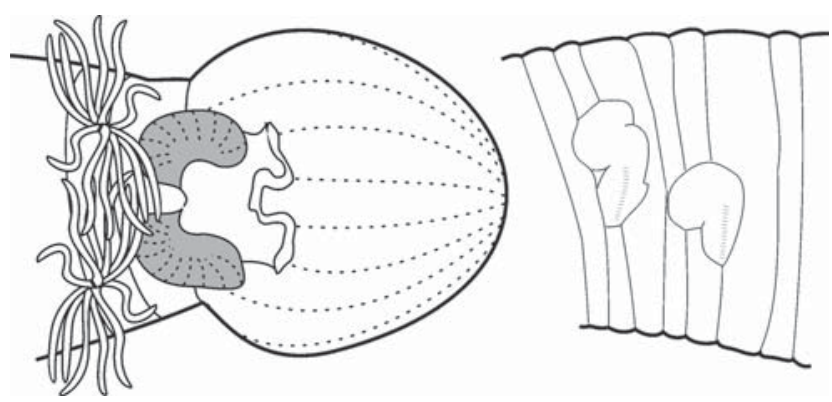

2. Peristomium in form of large proboscis ventrally; buccal tentacles attached to two fields (grey); abdominal neuropodia with large cirri Artacamini...

Artacama proboscidea Shelf Arcto-Boreal. - Peristomium without proboscis; buccal tentacles attached to single field; abdominal neuropodia without cirri 3

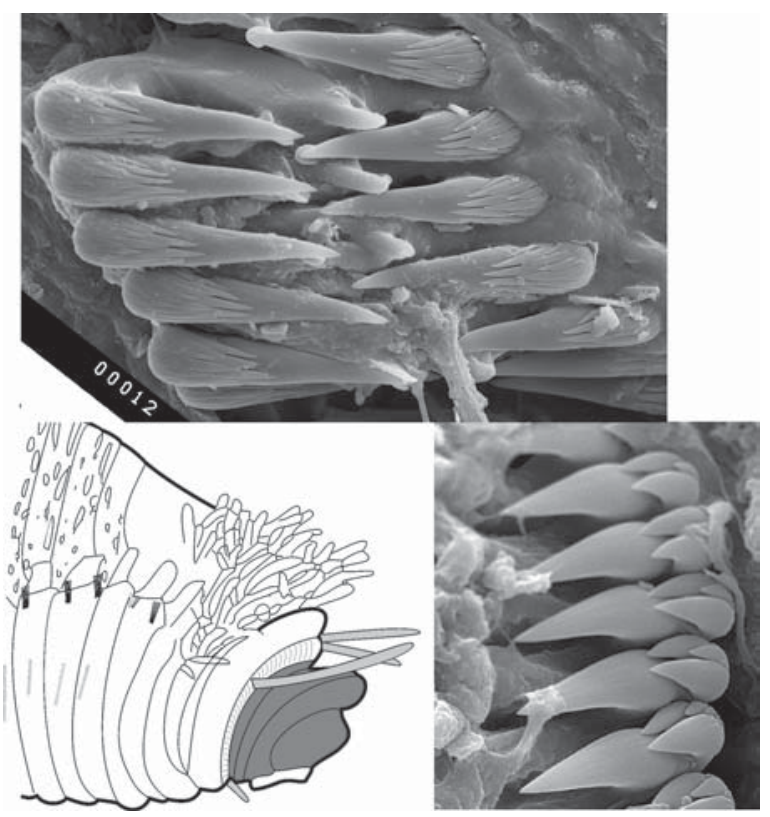

3. Uncini in posterior thorax in regular double rows, like a zipper (rarely two rows may be zipped and hardly distinguishable under the stereomicroscope, but still clear under a compound). Branchiae present or absent, often arborescent.

Terebellini...4

Abdominal neuropodia with double rows of uncini followed by neuropodia of a different shape with single row of uncini, if there is a shape change the number of rows has also changed.

- Uncini never in double rows (sometimes looped, but regular rows never present). Branchiae always present and never arborescent; dorsal surface often looks porous Thelepini...23

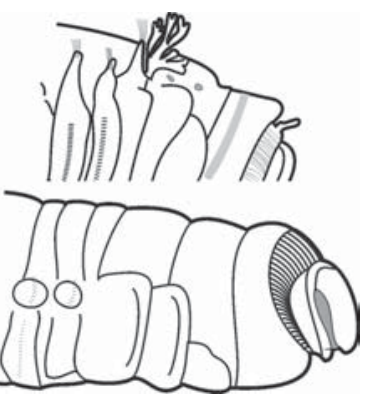

4. Branchiae present (if lost, attachment scars can be seen) 5

— Branchiae absent (nephridial papillae sometimes look like damaged branchiae!) 20

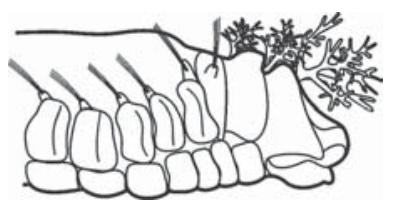

5. Anterior segment(s) with lateral lobes (projections on anterior edge) much longer than segment. 


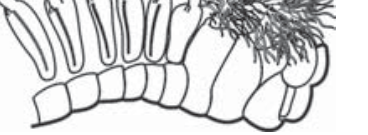

6. 1 or 2 pairs of branchiae 8

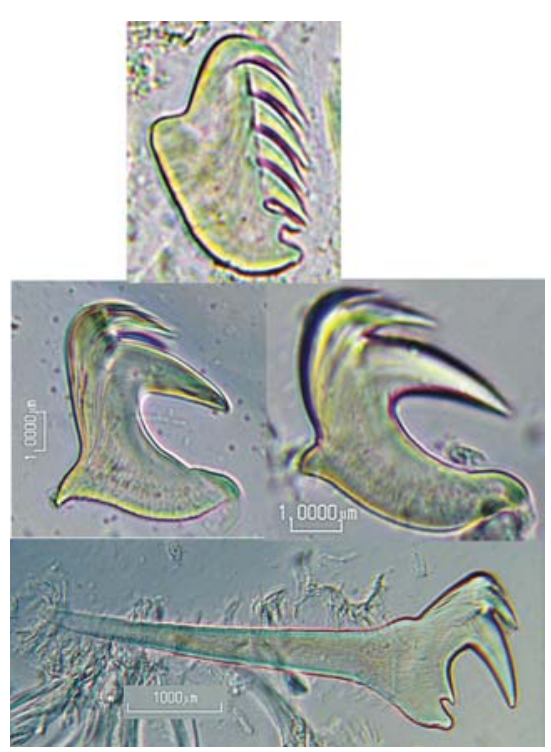

7. All uncini pectiniform (teeth almost equal).....

Loimia medusa Shallow water Lusitanian-tropical.

- All uncini avicular (main tooth + numerous smaller teeth above) without elongated base or with slightly elongated base

Lanice conchilega Shallow water low Boreal-tropical.

— Uncini of TU1, TU2 and TU3 avicular (main tooth + numerous smaller teeth above) with large elongated base

Pista cretacea Lusitanian.

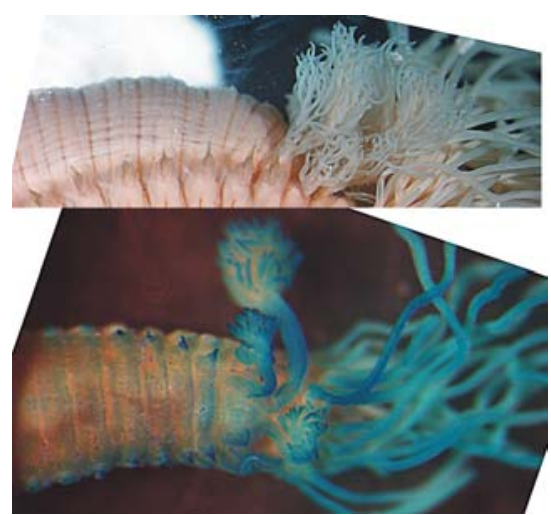

8. Branchiae dichotomous. 15-17 TC .9

- Branchiae bottle brush shaped. 17 TC 10

9. $15 \mathrm{TC}(=14 \mathrm{TU})$, sandy tube flattened and regularly sinuous

- $16 \mathrm{TC}(=15 \mathrm{TU})$, tube covered with sand, small stones, shell fragments etc., irregulary twisted

Pista maculata

Shelf and upper slope Arcto-Boreal.

- $17 \mathrm{TC}$ (=16 TU), tube muddy, usually with thin muddy projections

Pista mirabilis 


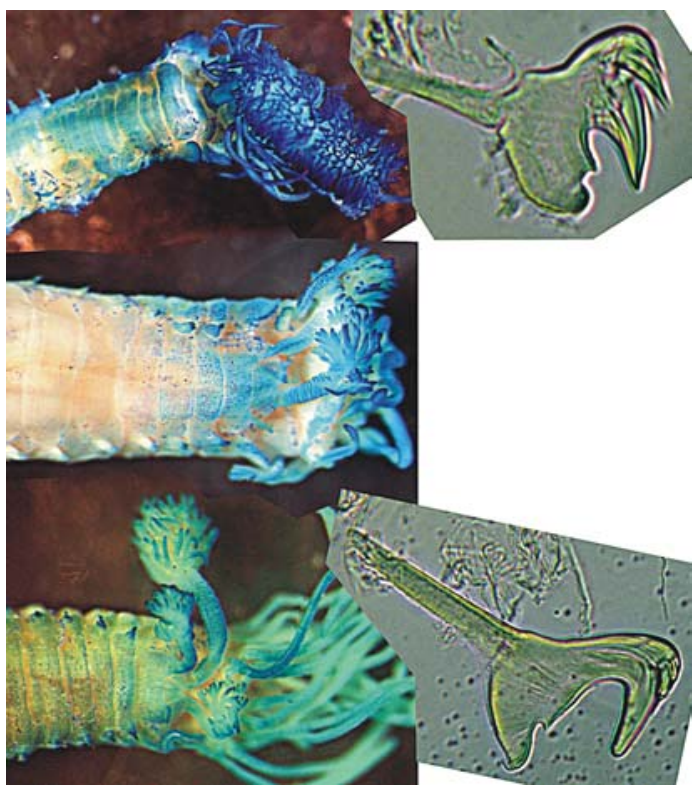

10. A single branchia in mid dorsal position. Uncini of TU1 with manubrium (take care, manubriums in this species can be easily broken and lost!)

Pista unibranchia

Lusitanian

- 1 pair of branchiae (one branchia usually much bigger than other). Uncini of TU1 with or without manubrium 11

- 2 pairs of branchiae, often with one undeveloped branchia so that there are 3 branchiae in total. Uncini of TU1 with manubrium

Pista mediterranea

Shallow water low Boreal-lusitanean.

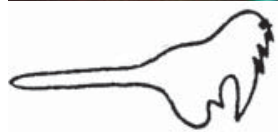

11. Thoracic uncini with long manubrium (manubrium absent in young worms, width $<1 \mathrm{~mm}$ ) Pista bansei

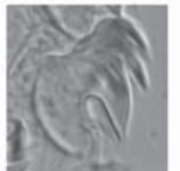

Mainly lower shelf Boreal-Lusitanian.

- All uncini without manubrium even in very large worms

Pista cristata

Shallow water low Boreal.

12. 2 pairs of branchiae 13

- 3 pairs of branchiae 15

13. All abdominal uncini in single row. 15-19 TC

Nicolea...14

— Uncini in double rows in less than eight anterior AU. 13 (rarely 14-15) TC

Paramphitrite birulai

Shelf.

— Uncini in double rows almost to end of body. 17-22 TC

Amphitritides gracilis

— Uncini in double rows almost to end of body. 25-29 TC Shallow water low Boreal-Lusitanian. Amphitritides kuehlmanni

14. $15 \mathrm{TC}$ Nicolea zostericola

- 17 (rarely 18 or 19 ) TC Probably shelf Arcto-Boreal.

15. Branchiae filiform. $17 \mathrm{TC}$ Nicolea venustula Shallow water low Boreal-Lusitanian - Branchiae dichotomous. 17-27 TC Amphitrite cirrata Shallow water widespread Boreal-Arctic.

16. $17 \mathrm{TC}$ 16

$-19 \mathrm{TC}$ Amphitrite groenlandica Shallow water high Boreal. $-21 \mathrm{TC}$ Amphitrite grayi Shallow water high Boreal.

- 23-27 TC 19

— Notochaetae almost to end of body 


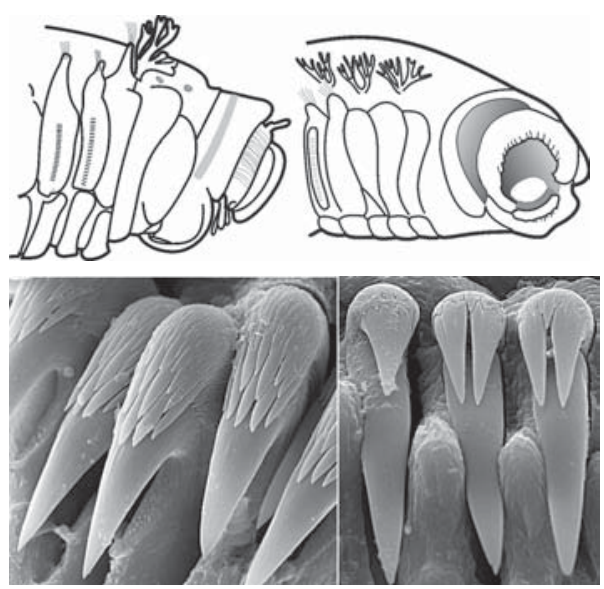

19. Uncini in double rows up to $\mathrm{C} 24-\mathrm{C} 28$

17. Anterior end with ventro-lateral collar

Eupolymnia nesidensis

Shallow water widespred Boreal.

— Anterior end without ventro-lateral collar..... 18

18. Uncini with numerous teeth above main tooth; eyes absent Amphitrite edwardsii Shallow water Boreal-Lusitanian. - Uncini with 1 or 2 teeth above main tooth; eyes present Eupolymnia nebulosa Shallow water widespred Boreal.

— Uncini in double rows almost to end of body Amphitrite figulus Shallow water widespred Boreal. Amphitrite rubra Shallow water Lusitanian.

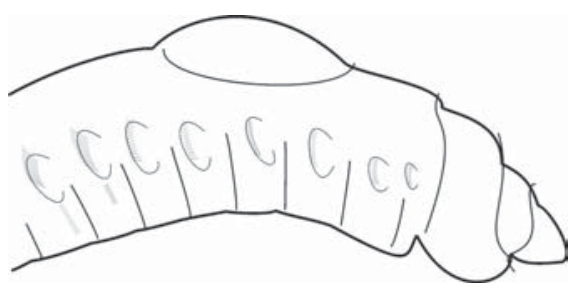
20. S2 with circular collar; uncini start from C7 or C8 (neuropodia without uncini may start earlier!). 17 TC

Laphania boecki Shelf arcto-Boreal. - Anterior segments may have dorsal folds and lateral lobes, but never with circular collar; uncini start from $\mathrm{C} 2$ or $\mathrm{C} 3$ 21 - Anterior segments without dorsal folds, lateral lobes or circular collar; neuropodia start near end of thorax or are present on abdomen only, upper lip enlarged and folded Polycirrinae...34

21. Uncini start from $\mathrm{C} 2$ 22

- Uncini start from C3; usually 16 TC (14-16 TC), uncini in double rows up to C16

Proclea graffi

Shallow water Boreal.

- Uncini start from C3, 20-23 TC, uncini in double rows up to C24-C27

Proclea emmi

Shallow water Boreal Pacific (in North Polar Basin in Chukchi Sea only).

22. $10 \mathrm{TC}$, uncini in double rows up to $\mathrm{C} 17$ (i.e. on 7 anterior abdominal segments).....

Leaena ebranchiata

Shallow water Arctic-high Boreal.

- Usually 11 TC (11-12 TC), uncini in double rows up to C15 (i.e. on 4 anterior abdominal segments)

Lanassa venusta

Shelf high Boreal and Arctic.

- 13-14 TC, uncini in double rows up to C16

Phisidia aurea

Shelf Boreal.

- 15 TC, uncini in double rows up to C15

Lanassa nordenskjoldi

— Notochaetae almost to the end of body Shelf high Boreal and Arctic. Baffinia hesslei

Shallow water high Boreal.

23. Upper lip wall-shaped; uncini start from TC3 or TC4 24

— Upper lip prolonged plate; uncini start from TC9

Parathelepus collaris Lusitanian. Cuba. 
24. Notochaetae from 1st branchiferous segment Streblosoma...25

- Notochaetae from 2nd branchiferous segment 27

25. Uncini looped from TU8.

Streblosoma hesslei

Lusitanian.

- All uncini in single rows 26

26. No more than 30 segments with notochaetae

Streblosoma intestinalis

— Up to 90 segments with notochaetae

Shelf Boreal.

Streblosoma bairdi

27. Lateral lobes on $\mathrm{S} 2-\mathrm{S} 4$

Shelf Boreal.

Euthelepus setubalensis

Lusitanian

- No lobes on S2-S4

Thelepus...28

28. 2 pairs of branchiae

Thelepus cincinnatus

Widely distributed.

- 3 pairs of branchiae 29

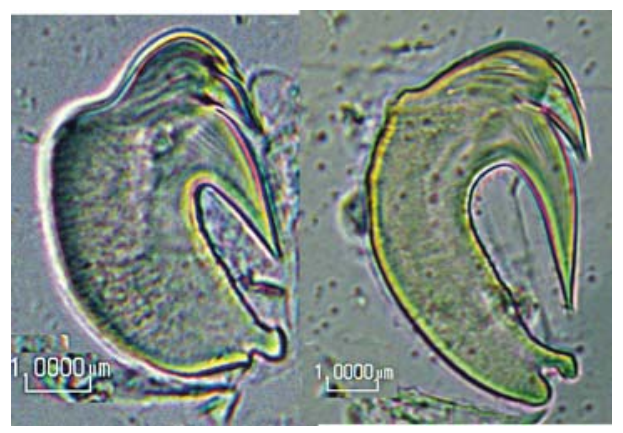

29. Prow (pointed tip) of uncinus poorly developed. Branchial filaments numerous .. Thelepus setosus Lusitanian.

- Prow of uncinus well developed with a button above. Branchial filaments few .....

Thelepus triserialis

Lusitanian.

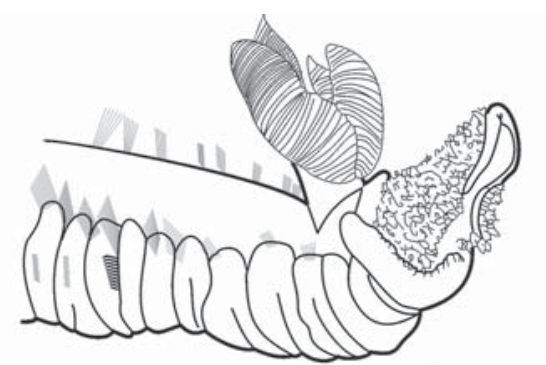

30. Branchiae with four branches with large transverse lamellae on a smooth stem

Terebellides...31

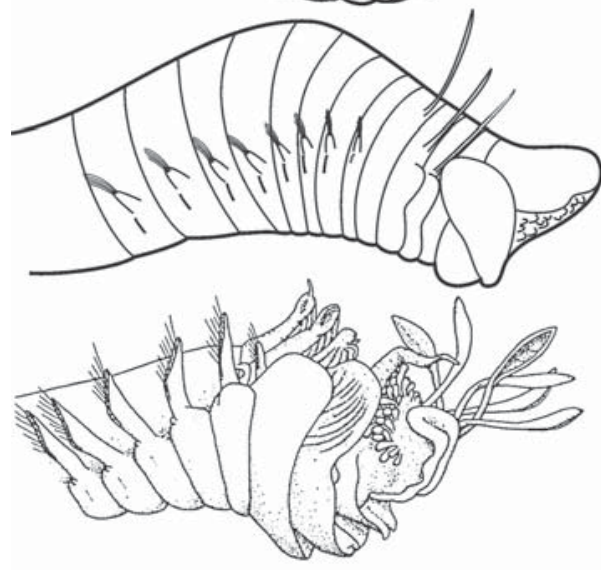

- All (2-4 pairs) branchiae cirriform 32

—First pair of branchiae cirriform, others foliaceous Octobranchus floriceps Distribution unknown, probably Boreal shelf. 


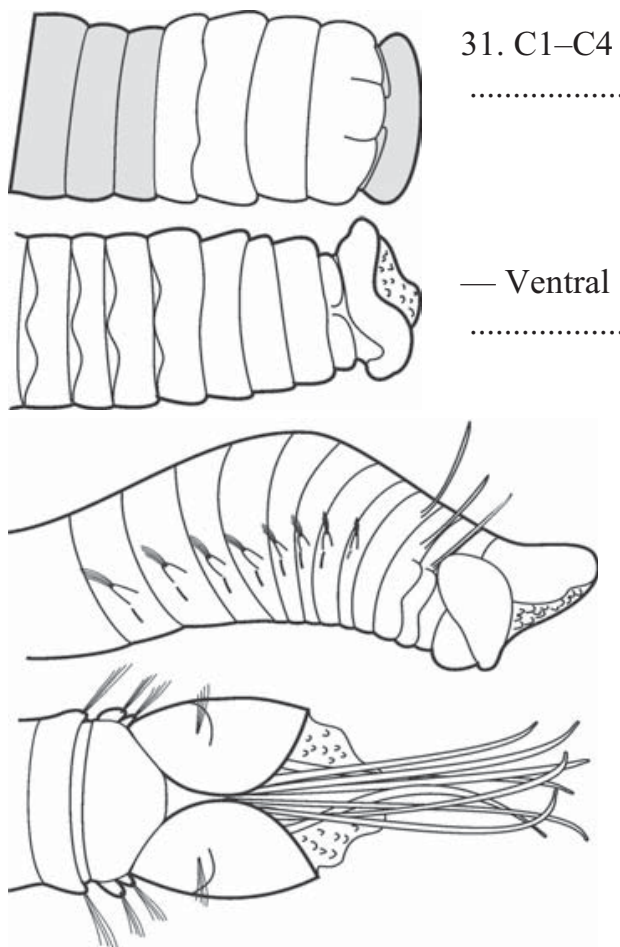

32. Branchial attachment points clear or covered by tentacles and upper lip; 2-3 pairs of branchiae, 15 TC. 33

33. 2 pairs of branchiae (may be hard to see if they are covered by tentacles and upper lip)

Trichobranchus roseus

- Branchial attachment points covered by lateral lobes; 4 pairs of branchiae, 16 TC

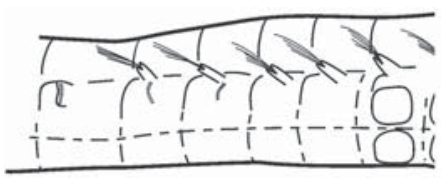

34. Neuropodia from TC7-TC14, both noto- and neuropodia present on at least 2 segments, neuropodia usually clearly visible. Ten to many $\mathrm{TC}$

Polycirrus (partim)...36

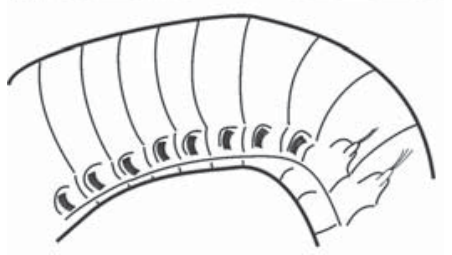

- Thorax with notopodia with notochaetae only, neuropodia from 1 st abdominal segment, i.e. no segments with both notoand neuropodia, usually neuropodia are clearly visible. Ten to several tens TC Polycirrus (partim)...40

- Thorax with notopodia with notochaetae only, neuropodia start from 5th-6th abdominal segment, i.e. no segments with both noto- and neuropodia, neuropodia usually difficult to see. Ten TC, body surface finely sculptured... Amaeana trilobata Shelf and slope Boreal. — Neuropodia totally absent, less than ten TC .... Lysilla...35

- Chaetae totally absent (nephridial papillae may imitate notopodia perfectly, but they have no chaetae). Body surface roughly sculptured....

Hauchiella tribullata 


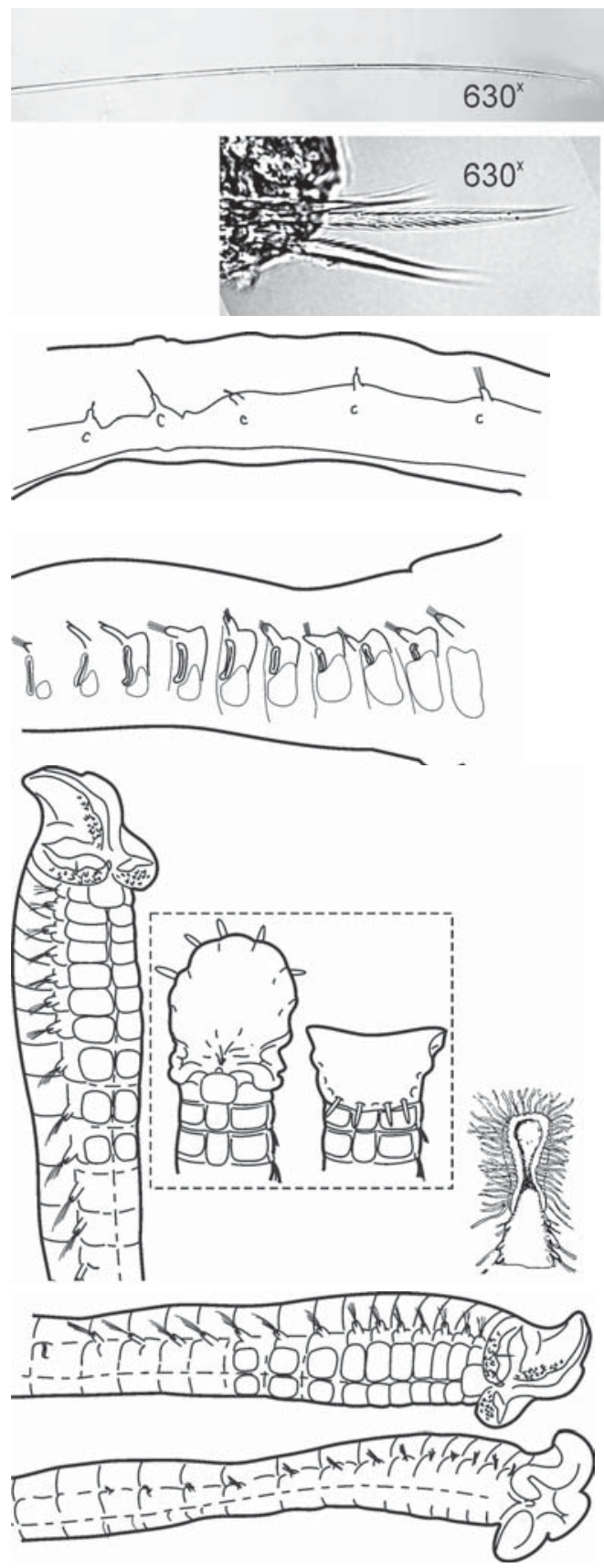

35. Body white or grey, notochaetae appear to be smooth under compound microscope, almost completely inside notopodia

Lysilla loveni

Shelf Boreal.

- Body reddish; notochaetae appear to be ciliated under compound microscope, greater part projects beyond notopodia . Lysilla nivea

?Lusitanian.

36. Neuropodia and neurochaetae clearly visible, neuropodia usually wider than notopodia .. 37 - Neuropodia and neurochaetae very small and hardly visible (use methyl blue!); neuropodia not wider than notopodia

37. First neuropodia 3 times shorter than 5 th .....

Polycirrus denticulatus

Lusitanian.

— All neuropodia of the same size 38

38. Upper lip tri- or four-lobed 39

- Upper lip convex, not lobed. More than 30 segments with notochaetae

Polycirrus aurantiacus Shelf low Boreal.

- Upper lip oval. 14-16 segments with notochaetae

Polycirrus haematodes

Shelf low Boreal. According to Holthe (1986) up to 22 segments with notochaetae.

39. Ventral shields distinct 40

- Ventral shields indistinct; notochaetae short, smooth, upper lip four-lobed, secondary annulation absent Polycirrus arcticus Shelf Boreal.

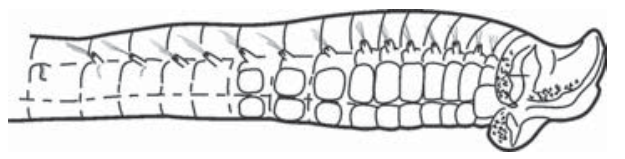

40. Upper lip trilobed, secondary annulation absent; notochaetae long, ciliated. 13-20 TC 


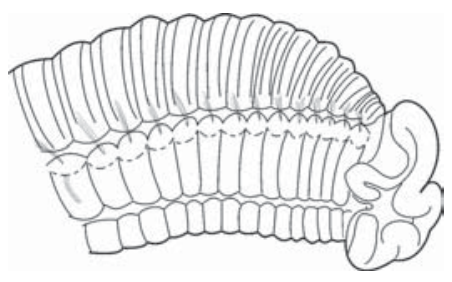

- Upper lip four-lobed, secondary annulation present; notochaetae long, smooth. 18-25 TC ....

Polycirrus fedorovi

Deep water Arctic.

- Upper lip trilobed; secondary annulation distinct at least on abdomen. 12-19 TC

Polycirrus tenuisetis

41. Upper lip trilobed

Polycirrus arenivorus

Lusitanian.

— Upper lip four-lobed
Polycirrus caliendrum

Lusitanian.
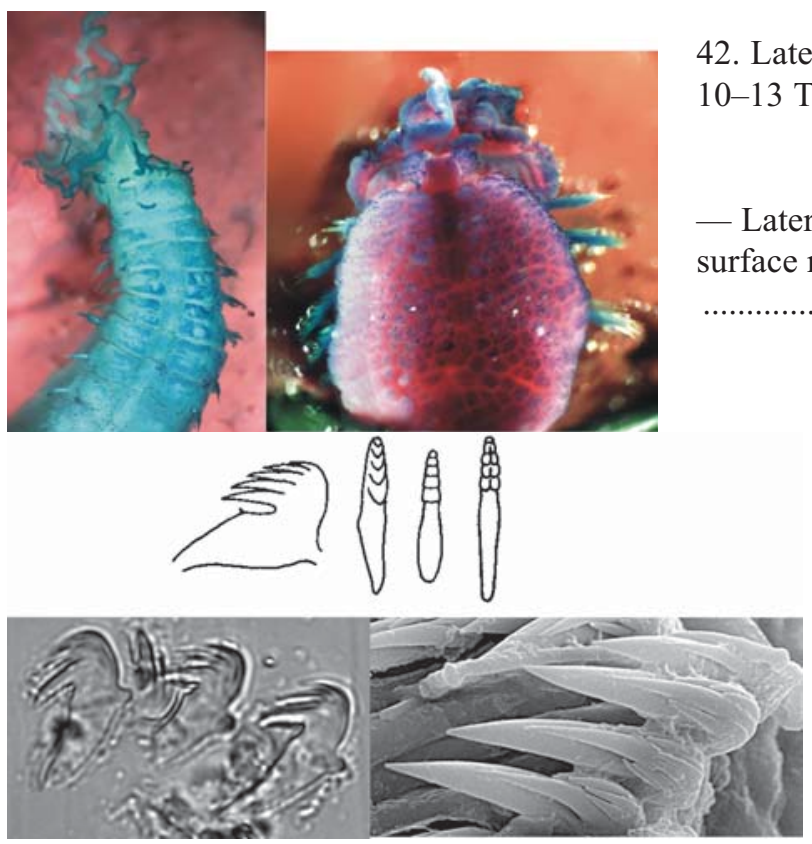

42. Lateral glandular shields distinct, smooth;

$10-13$ TC 43

- Lateral glandular shields indistinct, ventral surface rugose; 17-19 TC.....

Polycirrus plumosus Shelf low Boreal.

43. Uncini with several teeth of the same size Polycirrus latidens Shelf Boreal.

-Uncini avicular (one tooth is much larger than other)

Polycirrus medusa

Mainly shallow water Arcto-Boreal.

\section{Acknowledgements}

We'd like to thank the MES Ltd. team for very fruitful discussions of these keys. Also we thank all people who tested these keys and made remarks, which allowed us to improve them significantly: David Hall and Tim Worsfold (APEM Limited) and all participants of the workshops in Newcastle in 2008 and in MES Ltd. (Bath) in 2011. Dr. M. Ramos (Museo Nacional de Ciencias Naturales, Madrid) and Dr J. Parapar (Universidade da Coruña) made possible the visit of the first author to the Museo Nacional de Ciencias Naturales, Madrid financed by the Fauna Ibérica project. Special thanks are due to Samantha Lines, Thomas Scott-Heagerty (Gardline Marine Sciences Limited) and Tim Worsfold for transfer of data and material of the new species and to Vermilion Energy Inc., for permission to use the data and material.

Tim Worsfold reviewed the text and made edits to the English

The photos made: SEM at User Facilities Center of M.V. Lomonosov Moscow State University under financial support of Ministry of Education and Science of Russian Federation, compound at MES Ltd., and Museo Nacional de Ciencias Naturales, Madrid. 


\section{References}

Al-Hakim I., Glasby Ch.J. 2004. Polychaeta (Annelida) of the Natuna Islands, South China Sea // The Raffles Bulletin of Zoology. Suppl. No.11. P.25-45

Cocito S., Fanucci S., Niccolai I., Morri C., Bianchi C.N. 1990. Relationships between trophic organization of benthic communities and organic matter content in Tyrrhenian Sea sediments // Hydrobiologia. Vol.207. P.53-70.

Desbruyères D., Laubier L. 1977. Noanelia hartmanae gen. sp. n., Ampharetidae (Annelides Polychetes Sedentaires) abyssal du Golfe de Gascogne // Reish D.J. \& Fauchald K. (eds.). Essays on Polychaetous Annelids, in memory of Dr Olga Hartman, Los Angeles, California. P.199-207.

Ehlers E. 1887. Reports on the Annelids. Report on the results of dredging, under the Direction of L. F. Pourtales, during the years 1868-1870, and of Alexander Agassiz, in the Gulf of Mexico (1877-78), and in the Caribbean Sea (1878-79), on the U.S. coast survey steamer Blake, Lieut. Com. C.D. Sigsbee, U.S.N., and Commander J.R Bartlett, U.S.N. Commanding// Memoirs of the Museum of Comparative Zoology at Harvard College. No.15. P.i-vi, 1-335.

Fauvel P. 1927. Polychètes sédentaires. Addenda aux Errantes, Archiannélides, Myzostomaires // Faune de France. T.16. 494 p. (Reprinted by Kraus Reprint Nendelh/Liechtenstein in 1977).

Fauvel P. 1932. Annélides Polychètes provenant des campagnes de l'Hirondelie II (1911-1915) // Resultats des campagnes scientifiques accompiles sur son yacht par Albert Ier Prince Souverain de Monaco. T.85. 50 p.

Fauvel P. 1936. Contribution a la paune des Annélides Polychètes du Maroc // Mémoires de la société des sciences naturelles du Maroc. T.43. 143 p.

Gallardo V. 1968. Polychaeta from the Bay of Nha Trang, South Vietnam // Naga Report. Vol.4. Pt.3. P.35-279.

Gil J., Sardá R. 1999. New records of Annelida Polychaeta for the Portuguese fauna (with comments on some already known species) // Arquivos do Museu Bocage, nov. ser. T.3. No.19. P. 287-336.

Hartman O. 1965. Deep-water benthic polychaetous annelids off New England to Bermuda and other North Atlantic areas // Allan Hancock Foundation Occasional Paper No.28. 378 p.

Hartmann-Schröder G. 1971. Annelida, Borstenwürmer, Polychaeta // Die Tierwelt Deutschlands. Lfg.58. Jena: VEB Gustav Fischer Verlag. 594 S.

Hartmann-Schröder G. 1996. Annelida, Borstenwürmer, Polychaeta // Die Tierwelt Deutschlands und der angrenzenden Meeresteile nach ihren Merkmalen und nach ihrer Lebensweise. Lfg.58. Jena: VEB Gustav Fischer Verlag. 2. Auflage. $648 \mathrm{~S}$.

Holthe T. 1986. Polychaeta Terebellomorpha // Marine Invertebrates of Scandinavia. Universitets for laget. Oslo. Vol.7. 191 p.

Holthe T. 2002. One new genus and three new species of the Ampharetidae (Polychaeta: Terebellidae) from the BIOSHELF Project // Phuket Marine Biological Center Special Publication Vol.24. P.343-351.
Hutchings P. 1977. Terebelliform Polychaeta of the families Ampharetidae, Terebellidae and Trichobranchidae from Australia, chiefly from Moretonon Bay, Queensland. Rec. Aust. Mus. Vol.31. No.1. P.1-13.

Intès A., Le Loeuff P. 1977. Les annélides polychètes de Côte d'Ivoire. II. - Polychètes sédentaires - compte rendu systématique // Cah. O.R.S.T.O.M., sér. Océanographie. Vol.15. No.3. P.267-321.

Intès A., Le Loeuff P. 1984. Les annélides polychètes de Côte d'Ivoire // Océanographie Tropicale. Vol.19. P.3-24.

Jirkov I.A. 2001. [Polychaeta of the North Polar Basin]. Moskva: Yanus-K. 632 p. [in Russian].

Jirkov I.A. 2009. Revision of Ampharetidae (Polychaeta) with modified thoracic notopodia // Invertebrate Zoology. Vol.5. No.2. P.111-132.

Jirkov I.A. 2011: Discussion of taxonomic characters and classification of Ampharetidae (Polychaeta) // Italian Journal of Zoology. Vol.78. Supp1. P.78-94.

Jirkov I.A., Leontovich M.K. 2012. Biogeography of Polychaeta of the Eurasian North Polar Basin // Invertebrate Zoology. Vol.9. No.1. P.41-51.

Jirkov I.A., Safronova M.A., Leontovich M.K. 2001. Terebellidae Grube, 1851. In: Jirkov I.A. 2001. [Polychaeta of the North Polar Basin]. Moskva: Yanus-K. P. 495-531 [in Russian].

Kirkegaard J.B. 1959. The polychaeta of West Africa. Part I. Sedentary species // Atlantide Report. Vol.5. P.7117.

Laubier L. 1966. Decouverte d'une annelide polychète nouvelle en Mediterranée Occidentale: Auchenoplax crinita Ehlers, 1887 // Documents Faunistiques et Écologiques. Vie et Milieu. T.17. P.438-440.

Martinelli M., Santoni M., Casteixi A. 1998. Censimento Dei Policheti Dei Mari Italiani: Ampharetidae Malmgren, 1867 // Atti Soc. tosc. Sci. nat., Mem., Serie B. T.105. P.109-111.

Martínez J., Adarraga I. 2001. Distribución batimétrica de comunidades macrobentónicas de sustrato blando en la plataforma continental de Guipuzcoa (Golfo de Vizcaya) // Boletín del Instituto Español de Oceanografía. T.17. P.33-48.

Muir A.I. 2010. On the genera of Trichobranchidae (Polychaeta: Terebellida), with the redescription of Unobranchus// Italian Journal of Zoology. Vol.78. Supp1. P.140-147.

Parapar J., Moreira J. 2009. Polychaeta of the 'DIVAArtabria I' project (cruise 2002) in the continental shelf and upper slope off Galicia (NW Spain) // Cah. biol. Mar. Vol.50. P.57-78.

Parapar J., Helgason G.V., Jirkov I.A., Moreira J. 2011 a. Taxonomy and distribution of the genus Amphicteis (Polychaeta: Ampharetidae) collected by the BIOICE project in Icelandic waters // Journal of Natural History. Vol.45. No.23. P.1477-1499.

Parapar J., Helgason G.V., Jirkov I., Moreira J. 2011 b. Polychaetes of the genus Ampharete (Polychaeta: Ampharetidae) collected in Icelandic waters during the BIOICE project // Helgoland Marine Research. Vol.66. P.331-344.

Responsible editors E.N. Temereva, K.G. Mikhailov 


\section{Appendix. List of Terebellomor- pha species from the Eastern Atlantic and the North Polar Basin}

Synonymy is limited mainly to Fauvel (1927), Hartmann-Schröder (1971, 1996), Holthe (1976) and Jirkov (2001).

Only valid binomens are numbered.

Authors are given only for junior synonyms, not for the combinations rejected here.

\section{Pectinariidae}

- Amphictene auricoma see Pectinaria auricoma

- Cistenides granulata see Pectinaria granulata

- Cistenides hyperborea see Pectinaria hyperborea

- Lagis koreni see Pectinaria koreni

1. Pectinaria auricoma (O.F. Müller, 1776)

2. Pectinaria belgica (Pallas, 1766)

3. Pectinaria granulata (Linnaeus, 1767)

4. Pectinaria hyperborea (Malmgren, 1866)

5. Pectinaria koreni (Malmgren, 1866)

6. Petta pusilla Malmgren, 1866

\section{Ampharetidae}

Ampharetinae

1. Amage adspersa (Grube, 1863)

2. Amage auricula Malmgren, 1866

3. Amage gallasii Marion, 1875

4. Amage scotica Clark, 1952

5. Ampharete aculifrons (Grube, I860)

6. Ampharete baltica Eliason, 1955

7. Ampharete borealis (M. Sars, 1856)

8. Ampharete crassiseta Annenkova, 1929

9. Ampharete falcata Eliason, 1955

10. Ampharete finmarchica (M. Sars, 1864)

11. Ampharete goeesi Malmgren, 1866

12. Ampharete lindstroemi Malmgren in Hessle, 1917

13. Ampharete octocirrata (M. Sars, 1835)

14. Ampharete petersenae Jirkov, 1997

15. Ampharete sibirica (Wirйn, 1883)

- Alkmaria romijni see Hypania romijni

- Amagopsis klugei see Grubianella klugei

16. Ampharete vega (Wiř̆n, 1883)
17. Ampharete villenai Parapar, Helgason, Jirkov et Moreira, 2012

18. Amphicteis gunneri (M. Sars, 1835)

19. Amphicteis midas (Gosse, 1855)

20. Amphicteis ninonae Jirkov, 1985

21. Amphicteis sundevalli Malmgren, 1865

- Amphicteis vestis see Tanseimaruana vestis

22. Amphicteis wesenbergae Parapar, Helgason, Jirkov et Moreira, 2011

23. Amytasides macroglossus Eliason, 1955

24. Anobothrus gracilis (Malmgren, 1866)

25. Anobothrus laubieri (Desbruyères, 1978)

- Asabellides sibirica see Ampharete sibirica

26. Auchenoplax worsfoldi sp.n.

27. Eclysippe vanelli (Fauvel, 1936)

28. Glyphanostonum pallescens (Theel, 1879)

29. Grubianella klugei (Pergament et Khlebovich in Khlebovich, 1964)

30. Hypania romijni (Horst, 1919)

31. Hypania invalida (Grube, 1860)

32 Lysippe fragilis (Wollebaeck, 1912)

33. Lysippe labiaia Malmgren, 1866

34. Lysippe sexcirrata (M. Sars, 1856)

- Lysippides fragilis see Lysippe fragilis

- Melythasides laubieri see Anobothrus laubieri

- Mugga bathyalis see Sosane bathyalis

- Mugga wahrbergi see Sosane wahrbergi

- Sabellides borealis see Ampharete borealis

- Sabellides octocirrata see Ampharete octocirrata

- Samytha sexcirrata see Lysippe sexcirrata

35. Samythella elongata Verill, 1873

- Samythella neglecta Wollebaeck, 1912 see Samythella elongata

36. Sosane bathyalis (Holthe, 1986)

37. Sosane sulcata Malmgren, 1865

38. Sosane wahrbergi (Eliason, 1955)

39. Sosane wireni (Hessle, 1917)

- Sosanopsis wireni see Sosane wireni

40. Tanseimaruana vestis (Hartman, 1965)

41. Ymerana pteropoda Holthe, 1986

42. Zatsepinia rittichae Jirkov, 1986 


\section{Melinninae}

43. Melinna albicincta Mackie et Pleijel, 1995

44. Melinna collare Detinova, 1985

45. Melinna cristata (M. Sars, 1851)

46. Melinna elisabethae McIntosh, 1885

47. Melinna palmata Grube, 1870

- Melinnexis arctica see Melinnopsis arctica

- Melinnexis somovi Uschakov, 1957 see Melinnopsis arctica

48. Melinnopsis arctica (Annenkova, 1931)

\section{Terebellidae}

\section{Polycirrinae}

1. Amaeana trilobata (M. Sars, 1863)

2. Hauchiella tribulata (McIntosh, 1869)

3. Lysila loveni Malmgren, 1866

4. Lysila nivea Langerhans, 1884

5. Polycirrus arcticus M. Sars, 1825

6. Polycirrus arenivorus Caullery, 1916

The difference between Polycirrus arenivorus and $P$. caliendrum needs to be verified; it is possible that it is actually a single species, but the material is limited and does not provide a

7. Polycirrus aurantiacus Grube, 1860

8. Polycirrus caliendrum Claparède, 1868

9. Polycirrus denticulatus de Saint Joseph, 1894

10. Polycirrus haematodes (Claparède, 1864)

11. Polycirrus fedorovi Jirkov et Leontovich, 2001

12. Polycirrus lalidens E1 iason, 1962

13. Polycirrus medusa Grube, 1850

14. Polycirrus norvegicius (Wollebaek, 1912)

15. Polycirrus plumosus Wollebaek, 1912

16. Polycirrus tenuisetis Langerhans, 1880

\section{Terebellinae}

\section{Artacamini}

17. Artacama proboscidea Malmgren, 1866 Thelepini

18. Euthelepus setubalensis McIntosh, 1885

19. Parathelepus collaris (Southern, 1914)

20. Streblosoma bairdi (Malmgren, 1865)
21. Streblosoma intestinalis M. Sars, 1872

22. Thelepus cincinnatus (Fabricius, 1780)

23. Thelepus setosus (Quatrefages, 1865)

24. Thelepus triserialis (Grube, 1855)

\section{Terebellini}

- Amphitrite affinis Malmgren, 1866 see Amphitrite edwardsi syn.n.

According to the information available, we cannot state any difference between Amphitrite edwardsi and A. affinis. We have checked numerous specimens from British waters to the Sea of Japan and have found only one species. Investigation of type materials is needed to reach a final decision. However there is currently no means ot distinguish them, so we consider it best to treat them as a single species.

25. Amphitrite cirrata (O.F. Müller, 1776)

26. Amphitrite edwardsi (Quatrefages, 1865)

27. Amphitrite figulus (Dallyell, 1853)

- Amphitrite gracilis see Amphitritides gracilis

28. Amphitrite grayi (Malmgren, 1866)

29. Amphitrite groenlandica Malmgren, 1866

30. Amphitrite rubra (Risso, 1828)

- Amphitrite praecox Saint-Joseph, 1899 see Lanassa venusta

according to Fauvel's (1927) description, this species does not differ from Lanassa venusta.

31. Amphitrite variabilis (Risso, 1826)

32. Amphitritides gracilis (Grube, 1860)

33. Amphitritides kuehlmanni Arvanitidis et Koukouras, 1995

- Axionice flexuosa see Pista flexuosa

- Axionice maculata see Pista maculata

34. Baffinia hesslei (Annenkova, 1924)

35. Eupolymnia nebulosa (Montagu, 1818)

36. Eupolymnia nesidensis (Delle Chiaje, 1828)

37. Lanassa nordenskjoeldi Malmgren, 1866

38. Lanassa venusla (Malm, 1874)

39. Lanice conchilega (Pallas, 1766)

40. Laphania boecki Malmgren, 1866

- Leaena abranchiata Malmgren, 1866 see Leaena ebranchiata

41. Leaena ebranchiata (M. Sars, 1865)

42. Loimia medusa (Savigny, 1818)

Different species probably present in area.

- Neoamphitrite affinis see Amphitrite edwardsi

- Neoamphitrite figulus see Amphitrite figulus 
- Neoamphitrite grayi see Amphitrite grayi

- Neoamphitrite groenlandica see Amphitrite groenlandica

43. Nicolea venustula (Montagu, 1818)

44. Nicolea zostericola Oersted, 1844

45. Paramphitrite birulai (Ssolowiew, 1899)

- Paramphitrite tetrabranchia Holthe, 1976 see Paramphitrite birulai

46. Phisidia aurea Southward, 1956

47. Pista bansei Safronova, 1988

48. Pista cretacea (Grube, 1860)

49. Pista cristata (O.F. Müller, 1776)

50. Pista flexuosa (Grube, 1860)

51. Pista maculata (Dalyell, 1853)

- Pista malmgreni Safronova et Jirkov, 2001 see Pista mediterranea syn.n.

52. Pista mediterranea de Gaillande, 1970

53. Pista mirabills (McIntosh, 1885)

54. Pista unibranchia Day, 1963 Pistella lornensis see Pista cristata

55. Proclea emmi Annenkova, 1937

56. Proclea graffi (Langerhans, 1884)

- Proclea malmgreni Ssolowiew, 1889 see Proclea graffi
- Scionella lornensis Pearson, 1969 see Pista cristata

57. Terebella lapidaria Linnaeus, 1767

\section{Trihobranchinae}

58. Octobranchus floriceps Kingston et Mackie, 1980

59. Octobranchus sikorskii (Leonthovich, Jirkov, 2001) comb.n.

60. Terebellides gracilis Malm, 1874

- Terebellides irinae Gagaev, 2009 see Terebellides stroemii $\mathbf{s y n} . \mathbf{n}$.

Species perfectly fits within individual variation of $T$. stroemii. Within a single sample one can find typical $T$. stroemii along with typical $T$. irinae

61. Terebellides stroemii M. Sars, 1835

- Terebellides williamsae Jirkov, 1989 see Terebellides gracilis

62. Trichobranchus glacialis Malmgren, 1865

63. Trichobranchus roseus (Malm, 1874)

- Trichobranchus sikorskii see Octobranchus sikorskii 